CARPATHIAN JOURNAL OF FOOD SCIENCE AND TECHNOLOGY

journal homepage: http://chimie-biologie.ubm.ro/carpathian_journal/index.html

\title{
METAL AND LEAD-STRONTIUM ISOTOPE CHARACTERIZATION OF RED AND WHITE WINES FROM BUJORU, SMULTI AND OANCEA WINE CENTER, ROMANIA
}

\author{
Bora Florin-Dumitru ${ }^{1 *}$ \\ ${ }^{1}$ Research Station for Viticulture and Enology Târgu Bujor, Department of Physico-Chemistry and \\ Biochemistry, 805200 Târgu Bujor, Romania \\ *boraflorindumitru@gmail.com
}

https://doi.org/10.34302/crpifst/2019.11.3.11

Article history:

Received:

28 July 2019

Accepted:

28 August 2019

Keywords:

Dealu Bujorului;

Geographical discrimination;

Heavy metal content;

Isotope ratio.

\begin{abstract}
The goal of this research was to assess the potential of $\mathrm{Sr}$ and $\mathrm{Pb}$ composition and also isotopic signature of lead $\left({ }^{207} \mathrm{~Pb} /{ }^{206} \mathrm{~Pb},{ }^{208} \mathrm{~Pb} /{ }^{206} \mathrm{~Pb}\right.$ and $\left.{ }^{204} \mathrm{~Pb} /{ }^{206} \mathrm{~Pb}\right)$, strontium $\left({ }^{87} \mathrm{Sr} /{ }^{86} \mathrm{Sr}\right)$ of wines from Bujoru, Smulți and Oancea wine-growing centers from Dealu Bujorului vineyard. In this study 162 wine samples were investigated. The wine samples were obtained from micro-wine production under conditions of 2014-2016 from Dealu Bujorului vineyard. For all tested wine samples, the toxic metals contents were found in quantities below the limits established by legislation. The highest values were registered to wine obtained from Feteasca Neagra(2016) variety $(0.74275 \pm 0.00261)$ from Smulti wine-growing center, the lowest value of ${ }^{87} \mathrm{Sr} /{ }^{86} \mathrm{Sr}$ isotope ratio was recorded to wine obtained from Muscat Ottonel (2014) variety $(0.70165 \pm 0.00058)$ Oancea wine-growing center. A possible explanation for the higher mean of ${ }^{87} \mathrm{Sr} /{ }^{86} \mathrm{Sr}$ isotopic ration for wine can be the mineral consistency of the vineyard soil and its different eco-climatic conditions. Regarding ${ }^{206} \mathrm{~Pb} /{ }^{207} \mathrm{~Pb}$ isotopic ratios, we can say that the analyzed wine samples show shows traces of pollution comes from cars (automobile emissions) (if ${ }^{206} \mathrm{~Pb} /{ }^{207} \mathrm{~Pb}=1.1000-1.1400$ [automobile emissions]). The $\mathrm{Pb}$ isotope ratio from wines varies in range between 1.12305-1.18597 $\left({ }^{206} \mathrm{~Pb} /{ }^{207} \mathrm{~Pb}\right), \quad 2.09404-2.14190 \quad\left({ }^{208} \mathrm{~Pb} /{ }^{206} \mathrm{~Pb}\right)$ and $17.21089-17.70857$ $\left({ }^{206} \mathrm{~Pb} /{ }^{204} \mathrm{~Pb}\right)$ with average $1.15202\left({ }^{206} \mathrm{~Pb} /{ }^{207} \mathrm{~Pb}\right), 2.10878\left({ }^{208} \mathrm{~Pb} /{ }^{206} \mathrm{~Pb}\right)$ and $17.42240\left({ }^{206} \mathrm{~Pb} /{ }^{204} \mathrm{~Pb}\right)$. Heat map was discovered a separation of wine varieties for white of this red depending on elemental contents and ${ }^{206} \mathrm{~Pb} /{ }^{207} \mathrm{~Pb},{ }^{208} \mathrm{~Pb} /{ }^{206} \mathrm{~Pb},{ }^{206} \mathrm{~Pb} /{ }^{204} \mathrm{~Pb},{ }^{87} \mathrm{Sr} /{ }^{86} \mathrm{Sr}$ isotope ratios.
\end{abstract}

\section{Introduction}

Among the different criteria adopted to protect and promote food quality, the European Union (UE) has introduced, with the use of quality schemes, the link between territory and food (Sighinolfi et al., 2018). In this context, the protected designation of origin (PDO) represents the highest award that can be attributed to an aliment, and its implies that the entire food chain is within a delimited territory (Bora et al., 2018). Although there are many paper certifications for each food chain process that state for authenticity and quality arising from a particular geographical origin, none of these is based on objective criteria. In recent years, several attempts to develop tracking and tracing models for food processes have been made (Voerkelius et al., 2010; Baroni et al., 2011; Danezis et al., 2016).

Geographical origin and authenticity are factors affecting he overall perception of wines in terms of their quality and price, hence, being 
of great important to consumers and wine producers. We refer here to the origin certified products for which elevated prices are justified by the strict relationship which exist between the product quality and the areas of origin (Bora et al., 2018).

Starting from the fact that de term origin has a considerable importance, which correlates to the quality of wines also wine classification in terms of geographical and varietal origins became an argument of significant interest both for consumer and producers. In this respect, various analytical and statistical tools have been proposed for identifying wine are of production, form largest (e.g., country) (Almeida et al., 2016; Aoyama et al., 2017) (e.g., ward, district, wine centers) (Larcher et al., 2003; Avram et al., 2014; Coetzee et al., 2005; Bora et al., 2018).

When dealing with traceability models, it is of utmost importance to determine the identify of geographical indicator that is used to monitor the food chain from the field to the final product. For geographical traceability issues, one of the indicators that can be used is the primary or direct type, such as metal concentration or isotope ratios as bio-elements $\left({ }^{13} \mathrm{C} /{ }^{12} \mathrm{C}, \mathrm{D} / \mathrm{H}\right.$, ${ }^{18} \mathrm{O} /{ }^{16} \mathrm{O},{ }^{15} \mathrm{~N} /{ }^{14} \mathrm{~N}$, and $\left.{ }^{34} \mathrm{~S} /{ }^{32} \mathrm{~S}\right)$ or radiogenic heavy elements $\left({ }^{87} \mathrm{Sr} /{ }^{86} \mathrm{Sr},{ }^{145} \mathrm{~N} /{ }^{143} \mathrm{Nd}\right.$, and ${ }^{207} \mathrm{~Pb} /{ }^{206} \mathrm{~Pb}$ ) (Horn et al., 1993; Walker et al., 1989; Price et al., 2002; Fortunato et al., 2004; Trincherini et al., 2014; Marchionni et al., 2016; Aoyama et al., 2017).

Evaluation of natural abundance isotope ratios provides information on plant type or animal diet (carbon rations) and geographical origin (lead, strontium, deuterium and oxygen isotopic ratios) (Kelly et al., 2005). However, the ${ }^{13} \mathrm{C} /{ }^{12} \mathrm{C}$ ratios of plants are affected not only by the botanical origin ( $\mathrm{C} 3$ and $\mathrm{C} 4$ plants) but also by physiological and environmental factors that influence water used efficiently in the leaves. Stomatal conductance and intercellular and ambient $\mathrm{CO}_{2}$ concentrations are influenced by humidity, precipitation, temperature, water stress plant age, and maturation. Strontium is found in nature as three abundant isotopes: ${ }^{86} \mathrm{Sr}$ $(9.75-9.99 \%),{ }^{87} \mathrm{Sr}(6.94-7.14 \%),{ }^{88} \mathrm{Sr}(82.29-$ $82.77 \%)$ and ${ }^{84} \mathrm{Sr}(0.55-0.58 \%)$ as less abundant isotope (Berglund et al., 2011). The ${ }^{87} \mathrm{Sr}$ is radiogenic and therefore the ${ }^{87} \mathrm{Sr}$ content increases with time due to radioactive decay of ${ }^{87} \mathrm{Rb}$ (Petrini et al., 2015). Since the content of ${ }^{87} \mathrm{Sr}$ in soil varies with geological age and geographical location, the ${ }^{87} \mathrm{Sr} /{ }^{86} \mathrm{Sr}$ isotopic ratio can be used as a tracer for determining the geographical origin of wine (Vorster et al., 2010). Lead is found in nature as four abundant isotopes: ${ }^{206} \mathrm{~Pb}(20.84-27.48 \%),{ }^{207} \mathrm{~Pb}(17.62-$ $23.65 \%),{ }^{208} \mathrm{~Pb}(51.28-56.21 \%)$ and ${ }^{204} \mathrm{~Pb}(1.04-$ $1.65 \%$ ) as less abundant isotope (Rosman et al., 1998). Their abundance extensively varies because of different decay pathways from ${ }^{238} \mathrm{U}$, ${ }^{235} \mathrm{U}$ and ${ }^{232} \mathrm{Th}$ to ${ }^{206} \mathrm{~Pb},{ }^{207} \mathrm{~Pb},{ }^{208} \mathrm{~Pb}$ respectively (Bora et al., 2018). The $\mathrm{Pb}$ isotope of ore deposits and anthropogenic sources has their distinct isotopic ratios or signatures (Cheng et al., 2010). The $\mathrm{Pb}$ isotope ratio did not change in industrial or environmental processing and retained its retained its characteristic ratio from source ore (Ault et al., 1970).

Each geologic substratum of vineyards is liable to heave its own $\mathrm{Sr}$ isotope composition, which can potentially represent a fingerprint to trace the wine production provenance (Marchionni et al., 2016). The use of ${ }^{87} \mathrm{Sr} /{ }^{86} \mathrm{Sr}$ in tracking wine regional provenances was among the most pioneering application of isotope geology to other sciences (Barbaste et al., 2002). In most of the cases, however, the analytical uncertainty observed in $\mathrm{Sr}$ isotopes analyses of wines from literature is larger than most of the soil/rock isotopic variability, giving strong difficulties in matching data of wines with those from geologic substrata of the vineyards. Recently, high precision analytical method for determining ${ }^{87} \mathrm{Sr} /{ }^{86} \mathrm{Sr}$ has been provide enabling then direct comparison between data on wines with those of the pedological and geological substrata (Durante et al., 2015; Petrini et al., 2015).

Long lived isotope ratios of heavy metals of geological interest, such as ${ }^{87} \mathrm{Sr} /{ }^{86} \mathrm{Sr}$, ${ }^{206} \mathrm{~Pb} /{ }^{204} \mathrm{~Pb},{ }^{207} \mathrm{~Pb} /{ }^{204} \mathrm{~Pb},{ }^{208} \mathrm{~Pb} /{ }^{204} \mathrm{~Pb}$, have in the last decades gained importance in tackling the issues of geographical food traceability as well as in solving issues related with archaeological, 
environmental, medical and also forensic sciences (Hoogewerff et al., 2001; Voerkelius et al., 2010). This increasing consideration is mainly based on the fact that radiogenic isotopic ratios are extensively used either for tracking geological and environmental processes or dating Earth's materials and cosmological (Stewart et al., 1998). In addition, radiogenic isotope ratios are fractionated by biogenic processes or by low-temperature, and then their abundance in geological materials (minerals and rocks) depends upon: i) the initial radiogenic isotopic abundance, ii) on the age of the mineral/rock and iii) on their parent/daughter isotope ration (Tommasini et al., 2009).

The presence of lead in wine is associated with two major sources as follows: natural sources, which are due to the weathering of rocks, and human activity, which results from the use of fertilizers, pesticides and agricultural and food additives and environmental pollution (Larcher et al., 2003).

The goal of this study is to determine the elemental composition ( $\mathrm{Pb}$ and $\mathrm{Sr}$ ) of wine from Bujoru, Smulți and Oancea wine-growing centers from Dealu Bujorului vineyard and to assess their ability to discriminate between geographical origin of wines. Also, the study enhances the knowledge of the large-scale distribution of strontium $\left({ }^{87} \mathrm{Sr} /{ }^{86} \mathrm{Sr}\right)$ and lead $\left({ }^{206} \mathrm{~Pb} /{ }^{204} \mathrm{~Pb},{ }^{207} \mathrm{~Pb} /{ }^{204} \mathrm{~Pb},{ }^{208} \mathrm{~Pb} /{ }^{204} \mathrm{~Pb}\right)$ isotope ratios in wine from Dealu Bujorului vineyard. The wines from Smulți and Oancea winegrowing centers have not been analyzed yet regarding concentration of the elemental composition and distribution of strontium $\left({ }^{87} \mathrm{Sr} /{ }^{86} \mathrm{Sr}\right)$ and lead $\left({ }^{206} \mathrm{~Pb} /{ }^{204} \mathrm{~Pb},{ }^{207} \mathrm{~Pb} /{ }^{204} \mathrm{~Pb}\right.$, ${ }^{208} \mathrm{~Pb} /{ }^{204} \mathrm{~Pb}$ ) isotope ratio.

\section{Materials and methods}

\subsection{Experimental section}

\subsubsection{Study area}

For this study, a total of 162 wine samples (81 white wines and 3 red wines), samples originated from Bujoru, Smulți and Oancea wine-growing centers part of Dealu Bujorului vineyard $\left(45^{\circ} 52^{\prime} 10^{\prime \prime} \mathrm{N}, 27^{\circ} 55^{\prime} 8^{\prime \prime} \mathrm{E}\right)$. The Dealu Bujorului vineyard is characterized by an alternate landscape, from flat to hilly areas, with altitude between 100 and $230 \mathrm{~m}$ and the predominant soil is levigated chernozem having a clayey sand texture with $\mathrm{pH}$ between values 7.0 and 8.0. Although they have moisture deficit, natural conditions (ecoclimatic and ecopedological) offer viable ecosystem for the development of vineyard. The vineyard is crossed by the parallel $46^{\circ}$ latitude north, intersected by the $28^{\circ}$ longitude meridian. Dealu Bujorului vineyard belongs to Galati country. The specificity of the transition area is highlighted by the predominance of deposits of clays and sands. Versants were made from clay deposits and sandy sands.

The wines were selected from three consecutive vintages (2015, 2016 and 2017) were obtained by microvinification based on EC Regulation No. 2729/2000, consolidated with EC Regulation No. 2031/2006. Of these, 30 samples were from Bujoru wine-growing center, 56 from Smulți wine-growing center and 76 from Oancea wine-growing center. From the harvest of 2015, 2016 and 2017 were collected 54 wine samples.

\subsubsection{Climatological data}

The climate data used in this research was recorded through AgroExpert system at RSVE Bujoru and also from weather forecasting center. In experimental years the thermal balance values obtained are higher than multiannual average: global thermal balance $\left(\Sigma \mathrm{t}^{\circ} \mathrm{g}\right)$ was $3560.9{ }^{\circ} \mathrm{C}$ (3484.0 ${ }^{\circ} \mathrm{C}$ multiannual average), active thermal balance $\left(\Sigma \mathrm{t}^{\circ} \mathrm{a}\right)$ was $3526.6^{\circ} \mathrm{C} \quad\left(3387.5{ }^{\circ} \mathrm{C}\right.$ multiannual average) and beneficial thermal balance $\left(\Sigma \mathrm{t}^{\circ} \mathrm{u}\right)$ was $1736.6^{\circ} \mathrm{C} \quad\left(1700.1{ }^{\circ} \mathrm{C}\right.$ multiannual average). The precipitation quantity was lower $(405.4 \mathrm{~mm})$ then average of the last ten years $(505.7 \mathrm{~mm})$. During the growing season, the recorded precipitations values were $257.6 \mathrm{~mm}$, much lower than the multiannual average of $291.5 \mathrm{~mm}$ for Bujoru Wine Centre. The ecoclimatic conditions of Dealu Bujorului vineyard highlighted the exceptional viticultural characters of the Dealu Bujorului vineyard. These characters were found in the authenticity 
and specificity of a wide assortment of wine obtained in the studied area.

\subsubsection{Sample collection and microvinification process}

The white cultivars consisted of Muscat Ottonel, Feteasca alba ad Feteasca regala, while red cultivars were Feteasca neagra, Merlot and Cabernet Sauvignon under the conditions of 2015, 2016 and 2017. The wine samples resulted from micro-wine production. Micro-wine production was done according to the methodology describe by Bora et al., 2016; Bora et al., 2018, Donici et al., 2019. All wines were providing by the wineries as finished wines in $750 \mathrm{~mL}$ bottles with cork stoppers and were stored at $3-4^{\circ} \mathrm{C}$ before analysis. All vines were planted since 1979, and the vine plantation was organized with $2.2 \times 1 \mathrm{~m}$ distance between rows and plants. Vines were pruned according to the Guyot system and were grown on speliers.

\subsection{Material and methods used}

\subsubsection{Reagents and solution}

\subsubsection{Blanks}

An appropriately diluted indium intern standard stock solution was prepared from 1000 $\mathrm{mg} / \mathrm{L}$ In ICP-MS standard solution (Alpha Aeser).

The method blank for the 1:2 diluted wine samples was prepared to contain $7.6 \%$ ethanol in $1 \%$ nitric acid. The blank for the digested wine samples was prepared by subjecting the solution used for digestion $(7 \mathrm{~mL} 65 \%$ nitric acid plus 1 $\mathrm{mL} \mathrm{H}_{2} \mathrm{O}_{2}$ ) to the microwave digestion program and diluting to $50 \mathrm{~mL}$ with Milli-Q water.

\subsubsection{Physical and chemical analysis}

The physical and chemical analysis of young wine were performed in the Winemaking Laboratory of the RSDVV Bujoru and were applied in accordance to the methods of analysis described in the Compendium of international methods of analysis of wines and musts and to the Romanian STAS methods (Bora et al., 2016; Bora et al., 2018). During this analysis the following parameters were determined: alcohol (\% vol.) - was determined using the ebulliometric method, STAS 6182/6-70; total acidity $\left(\mathrm{g} / \mathrm{L} \mathrm{C}_{4} \mathrm{H}_{6} \mathrm{O}^{6}\right)$ - titrimetric method, STAS 6182-1:2008; volatile acidity ( $\left.\mathrm{g} / \mathrm{L} \mathrm{CH}_{3} \mathrm{COOH}\right)$ according to STAS 6182-2:2008; residual sugar (mg/L) - according STAS 6182/17-81. The next parameters: acetic acid (g/L); amino nitrogen $(\mathrm{mg} / \mathrm{L})$; tartaric acid $(\mathrm{g} / \mathrm{L})$; L-lactic acid $(\mathrm{g} / \mathrm{L})$; D-malic acid ( $\mathrm{g} \mathrm{L}$ ) were determinate using spectrophotometric method.

\subsubsection{Standards}

For analysis of the main quality of parameters of wine, all reagents used for calibration were of analytical grade (TDI Tecnología Difusión Ibérica, S.L. Fr.).

Two elements $(\mathrm{Pb}$ and $\mathrm{Sr})$ were determined in order to assess their ability to discriminate wines by geographical origin. The analysis was made using multielement analysis and ICP-MS technique, after an appropriate dilution, using external standard calibration method. The calibration was performed using XXICertiPUR multielement standard. The working standards and the control sample were prepared daily from the intermediate standards that were prepared from the stock solution. The intermediate solutions stored in polyethylene bottles and glassware was cleaned by soaking in $10 \% \mathrm{v} / \mathrm{v}$ nitric acid for 24 hours and rinsing at least ten rimes with ultrapure water $\left(18.2 \mathrm{M} \Omega \mathrm{cm}^{-1}\right.$ ultrapure water-Types 1). The accuracy of the methods was evaluated by replicate analyses of fortified samples ( $10 \mu \mathrm{L}-10 \mathrm{~mL}$ concentrations) and the obtained values ranged between 0.8-13.1 percent, depending on the element. The global recovery for each element was estimated and the obtained values were between 84.6-100.9\% (Bora et al., 2016; Bora et al., 2018).

Table 1. Instrumental conditions for the determination of each element (ICP-MS)

\begin{tabular}{|c|c|c|c|c|}
\hline Element & $\begin{array}{c}\text { Correlation } \\
\text { coefficient }\end{array}$ & $\begin{array}{l}\text { LoD* } \\
(\mu \mathrm{g} / \mathrm{L})\end{array}$ & $\begin{array}{c}\mathrm{LoQ} * * * \\
(\mu \mathrm{g} / \mathrm{L})\end{array}$ & $\begin{array}{c}\text { BEC*** } \\
(\mu \mathrm{g} / \mathrm{L})\end{array}$ \\
\hline $\mathrm{Sr}$ & 0.9999 & 0.1434 & 0.4775 & 0.955 \\
\hline $\mathbf{P b}$ & 0.9999 & 0.0003 & 0.0010 & 0.002 \\
\hline
\end{tabular}


For quality control purpose, blanks and triplicates samples $(n=3)$ were analyzed during the procedure. The variation coefficient was under 5\% and detection limits (ppb) were determined by the calibration curve method. Limit of detection (LoD) and Limit of quantification (LoQ) limits were calculated according to the next mathematical formulas: $\mathrm{LoD}=3 \mathrm{SD} / \mathrm{s}$ and $\mathrm{LoQ}=10 \mathrm{SD} / \mathrm{s}(\mathrm{SD}=$ estimation of the standard deviation of the regression line; $\mathrm{s}=$ slope of the calibration curve) (Table 1).

For calibration and to verify the achieved accuracy and precision, ten NIST-SRM 987 and NIST-SRM 982 analysis results were pooled together with the calculated relative standard deviation presented in Table 2.

Table 2. Lead isotopic ration and Lead isotopic ration determination precision and accuracy based on the NIST SRM 982 (Lead)

NIST SRM 987 (Strontium) $(\mathrm{n}=10)$

\begin{tabular}{|c|c|c|c|}
\hline $\begin{array}{c}{ }^{207} \mathbf{P b} /{ }^{206} \mathbf{P b} \\
(\mathbf{a})\end{array}$ & $\begin{array}{c}{ }^{208} \mathbf{P b} /{ }^{206} \mathbf{P b} \\
(\mathbf{b})\end{array}$ & $\begin{array}{c}{ }^{204} \mathbf{P b} /{ }^{206} \mathbf{P b} \\
(\mathbf{c})\end{array}$ & $\begin{array}{c}{ }^{87} \mathbf{S r} /{ }^{86} \mathbf{S r} \\
(\mathbf{d})\end{array}$ \\
\hline 0.46179 & 0.99736 & 0.02270 & 0.71117 \\
\hline
\end{tabular}

${ }^{\mathrm{a}}$ Certified value $={ }^{207} \mathrm{~Pb} / 206 \mathrm{~Pb}(0.46707 \pm 0.00020)$;

${ }^{\mathrm{b}}$ Certified value $={ }^{208} \mathrm{~Pb} /{ }^{206} \mathrm{~Pb}(1.00016 \pm 0.00036) ;$

${ }^{\mathrm{c}}$ Certified value $={ }^{204} \mathrm{~Pb} /{ }^{206} \mathrm{~Pb}(0.027219 \pm 0.00027)$;

${ }^{\mathrm{d}}$ Certified value $={ }^{87} \mathrm{Sr} /{ }^{86} \mathrm{Sr}(0.71034 \pm 0.00026)$.

Based on the obtained results, it was verified that, applying quadrupole ICP-MS, relative standard deviation and reproducibility of approximately $0.5 \%$ for ${ }^{87} \mathrm{Sr} /{ }^{86} \mathrm{Sr},{ }^{206} \mathrm{~Pb} /{ }^{207} \mathrm{~Pb}$ and ${ }^{208} \mathrm{~Pb} /{ }^{206} \mathrm{~Pb}$ are feasible. The results were in agreement with those reported by Avram et al., 2014; Bora et al., 2016; Bora et al., 2018.

\subsubsection{Sample preparation for determination of heavy metals and isotopic ration from wine using ICP-MS}

For the determination of elements from wine samples were used an amount of $0.5 \mathrm{~mL}$ wine and adjust $8 \mathrm{~mL}\left(7 \mathrm{~mL} \mathrm{HNO}_{3} 65 \%+1 \mathrm{~mL} \mathrm{H}_{2} \mathrm{O}_{2}\right)$ were placed in a clean Teflon digestion vessel, after 15-30 minutes the mineralization was performed using a microwave system Milestone START D Microwave Digestion System set in three steps: step I (time 10 min., temperature $200^{\circ} \mathrm{C}$ ), step II (time 15 min., temperature $200^{\circ} \mathrm{C}$ ) and step III (time $40 \mathrm{~min}$., ventilation temperature $32^{\circ} \mathrm{C}$ ). After mineralization, samples were filtered through a $0.45 \mathrm{~mm}$ filter and brought to a volume of $50 \mathrm{~mL}$. The $\mathrm{Pb}$ and $\mathrm{Sr}$ isotope ration in the analysed wine samples $\left({ }^{206} \mathrm{~Pb} /{ }^{207} \mathrm{~Pb},{ }^{208} \mathrm{~Pb} /{ }^{206} \mathrm{~Pb},{ }^{206} \mathrm{~Pb} /{ }^{204} \mathrm{~Pb},{ }^{87} \mathrm{Sr} /{ }^{86} \mathrm{Sr}\right.$, were determined according to the methodology indicated by Bora et al., 2016; Bora et al., 2018.

Table 3. Standard additions for checking accuracy of the microwave digestion ICP-MS method $(n=3)($ SRM 1643e)

\begin{tabular}{|c|c|c|}
\hline Element & $\begin{array}{c}\text { Certified } \\
\text { Concentration } \\
(\mathbf{m g} / \mathbf{L})\end{array}$ & $\begin{array}{c}\text { Measured } \\
\text { Concentration } \\
(\mathbf{m g} / \mathbf{L})\end{array}$ \\
\hline $\mathbf{S r}$ & $314.00 \pm 19.00$ & $314.09 \pm 09.06$ \\
\hline $\mathbf{P b}$ & $19.63 \pm 0.21$ & $19.13 \pm 0.09$ \\
\hline
\end{tabular}

In order to confirm the best-chosen conditions for wine digestion standard additions for checking accuracy of the microwave digestion and recoveries were calculated (Table 3 ). The digestion seemed visually completed in all of the combinations, but the spiked recoveries showed significant differences for total elements content $(p-$ Value $=0.005)$.

\subsubsection{Instrumentation}

In order to get a wider range of data about the quality of the tested wine and to determine the acetic acid, amino acid, tartaric acid, L-lactic acid, and M-malic acid the MIURA ONE I.S.E. S.r.1., Rome, Italy device was used.

All analyses were carried out with iCAP Q Thermo scientific model Coupled Plasma Mass Spectrometer (ICP-MS) equipped with nikel cones, a peristaltic sample delivery pump and a Cetac auto sampler. Instrumental conditions for the ICP-MS were optimized, after completing the mass calibration and detector crosscalibration, by following a manual tuning procedure using Thermo Tuning Solution A containing a manual tuning procedure using $\mathrm{Ni}$, $\mathrm{In}, \mathrm{Ba}, \mathrm{Ce}, \mathrm{Pb}, \mathrm{Bi}$ and $\mathrm{U}$ at $10 \mu \mathrm{g} / \mathrm{L}$, and $\mathrm{As}$ and Se at $100 \mu \mathrm{g} / \mathrm{L}$. For data acquisition the ICP-MS was operated in peak pump mode, with a dwell time of $20 \mathrm{~ms}, 100$ sweeps. Five replicate measurements were made. The isotopes ${ }^{86} \mathrm{Sr}$, 
${ }^{87} \mathrm{Sr},{ }^{204} \mathrm{~Pb},{ }^{206} \mathrm{~Pb},{ }^{207} \mathrm{~Pb}$ and ${ }^{208} \mathrm{~Pb}$. The elements selected are mostly metals and are considered to be useful as possible indicators of geographical origin, since they are not generally affected by vinification and are therefore in principle providing a link with the soil composition. Most of them have been tested in a number of previous studies (Almeida et al., 2003; Coetzee et al., 2005; Moreno et al., 2008; van der Linde et al., 2010).

The argon used was of $99.99 \%$ purity (Messer, Austria). The instrument was daily optimized to give maximum sensitivity for $\mathrm{M}^{+}$ ions and the double ionization and oxides monitored by the means of the rations between $\mathrm{Ba}^{2+} / \mathrm{Ba}^{+}$and $\mathrm{Ce}^{2+} / \mathrm{CeO}^{+}$, respectively, these always being less than $2 \%$. The experimental conditions were: argon flow on nebulizer $(0.82$ $\mathrm{L} / \mathrm{min}$.), auxiliary gas flow $0.80 \mathrm{~L} / \mathrm{min}$., argon flow in plasma $15 \mathrm{~L} / \mathrm{min}$., lens voltage $7.30 \mathrm{~V}$; $\mathrm{RF}$ power in plasma $1100 \mathrm{~W}$, spray chamber temperature $\left(2.42 \pm 1.00^{\circ} \mathrm{C}\right)$. Accuracy was calculated for the elements taken into consideration $(0.5-5.0 \%)$.

To reduce molecular interferences, the data of ${ }^{86} \mathrm{Sr},{ }^{87} \mathrm{Sr},{ }^{204} \mathrm{~Pb},{ }^{206} \mathrm{~Pb},{ }^{207} \mathrm{~Pb}$ and ${ }^{208} \mathrm{~Pb}$ were collected using Collision Cell Technology (CCT). Tuning in CCT mode using $7 \% \mathrm{H} / \mathrm{He}$ gas was carried oud using Autotune function and Thermo Tuning Solution A. To enhance the stability of the analyte signal, the sample uptake of the peristaltic pump was regularly replaced.

\subsubsection{Statistical analysis}

Data analysis was performed to test if significant differences can be highlighted between the geographical origin of wines samples by district. The statistical interpretation of the results was performed using the Duncan test, SPSS Version 24 (SPSS Inc., Chicago, IL., USA). The statistical processing of the results was primarily performed in order to calculate the following statistical parameters: average and standard deviation. The statistical analysis was performed by using the analysis of variance (ANOVA) followed by multiple comparisons tests in which the level of significance was set at $p \leq 0.05$. ANOVA determined, for each parameter, the mai effect of the region and of the year of harvest on the multiisotopic and multielement composition of samples. Secondly, the data were processed using the Linear Discriminant Analysis (LDA).

Multivariate chemometric method was used as a supervised learning technique for the differentiation of wines intro groups on the basis of grape variety and year of production and finding markers which showed a significant discrimination value (variables with Wilk's lambda near zero, $p$ value <0.05). Stepwise linear discriminant analysis (LDA) was used to identify significant tracers for classification to the geographical discrimination of the wines samples. At each step, the variable with the best discriminating power, as described by an Fstatistic and $p<0.0001$, was entered into the model and then several discriminant functions were obtained. Stepwise Discriminant Analysis (LDA) was used to designate suitable variables for classification of the samples, eliminating the variables that do not contribute to discrimination of the wine. In order to validate the proposed statistic model, based on variables which showed higher significance in first LDA assessment, we performed a second Linear Discriminant Analysis (LDA) for the test set consisting of wines used to build statistical model (training set) together with data from other wine samples that are not included in the first LDA (control-set). Cross-validation was applied to determine the optimal number of variables required to obtain robust models. Linear discriminant analysis (LDA) was performed using Microsoft Excel 2016 and XLSTAT Addinsoft version 15.5.03.3707.

\section{Results and discussions}

\subsection{Analysis of the main quality of parameters of wine}

Based on the results regarding the qualitative assessment of the tested varieties, they have a very good suitability in the studied areas. In terms of quality rating, they display particular characters of the varieties, as well as the ecoclimatic conditions and ecopedological influence on the quality of wine (Table 4). 
The physico-chemical analysis of wines showed that the highest alcohol content was recorded at the Merlot variety (15.40\% vol.), followed by Feteasca neagra ( $15.17 \%$ vol.). The highest level of acidity was recorded at the Muscat Ottonel $\left(6.37 \mathrm{~g} / \mathrm{L} \quad \mathrm{C}_{4} \mathrm{H}_{6} \mathrm{O}_{6}\right)$ and the lowest acidity in the Feteasca regala $(4.36 \mathrm{~g} / \mathrm{L}$ $\mathrm{C}_{4} \mathrm{H}_{6} \mathrm{O}_{6}$ ).

3.2. ${ }^{206} \mathrm{~Pb} /{ }^{207} \mathrm{~Pb}, \quad{ }^{208} \mathrm{~Pb} /{ }^{206} \mathrm{~Pb}, \quad{ }^{206} \mathrm{~Pb} /{ }^{204} \mathrm{~Pb}$, ${ }^{87} \mathrm{Sr} /{ }^{86} \mathrm{Sr}$, isotope ratio in wine samples Bujoru, Smulți and Oancea Wine Center

Lead isotopic analysis of wines from France (Bordeaux) showed that lead in the wines changed over time and reflect the dominant source of atmospheric lead pollution in southern of France (Médina et al., 2000). Other researchers have found that lead isotopic compositions in wine may not always reflect those of leaded petrol, but reflect the isotopic signature of local, dominant metallurgical industries (Galani-Nikolakaki et al., 2002). These studies confirm atmospheric deposition as being the dominant contributor to the lead total concentration and isotopic composition from wines. Some studies have shown that contamination from tin-lead foil capsules in the presence of corrosion and cork disintegration can dominate the source of lead from wines (Gulson et al., 1992). Other researchers have attributed the lead in wine to machinery or additives used during the vinification process where environmental contamination in this case is low (Almeida et al., 2003). In Central Europe, the lead isotopic ratio, as signatures of pollution sources, ranges from relatively high ${ }^{206} \mathrm{~Pb} /{ }^{207} \mathrm{~Pb}$ ratios (natural $\mathrm{Pb}$, coals, fly ashes, ${ }^{206} \mathrm{~Pb} /{ }^{207} \mathrm{~Pb}=$ 1.1700 - 1.2200) to low ${ }^{206} \mathrm{~Pb} /{ }^{207} \mathrm{~Pb}$ values (gasoline, petrol combustion, ${ }^{206} \mathrm{~Pb} /{ }^{207} \mathrm{~Pb}=$ 1.0600 - 1.1400) [30].

The original composition of soil samples retains its chemical composition from the geographical area it belongs to (Shirahata et al., 1980; Gulson et al., 1981; Elbaz-Poulichet et al., 1984; Bora et al., 2013). This property is useful in order to identify of the source of lead in a subjected wine sample provided that the measurements of the isotope ratio is precise and accurate.

The $\mathrm{Pb}$ isotope ratio from wines (Table 5) varies in range between $1.12305-1.18597$ $\left({ }^{206} \mathrm{~Pb} /{ }^{207} \mathrm{~Pb}\right), 2.09404-2.14190\left({ }^{208} \mathrm{~Pb} /{ }^{206} \mathrm{~Pb}\right)$ and $17.21089-17.70857\left({ }^{206} \mathrm{~Pb} /{ }^{204} \mathrm{~Pb}\right)$ with average $\quad 1.15202 \quad\left({ }^{206} \mathrm{~Pb} /{ }^{207} \mathrm{~Pb}\right), \quad 2.10878$ $\left({ }^{208} \mathrm{~Pb} /{ }^{206} \mathrm{~Pb}\right)$ and $17.42240 \quad\left({ }^{206} \mathrm{~Pb} /{ }^{204} \mathrm{~Pb}\right)$. Regarding ${ }^{206} \mathrm{~Pb} /{ }^{207} \mathrm{~Pb}$ isotope ratios based on analyses it can be concluded that the wine obtained from vine varieties grown in the Bujoru wine-growing centers how's traces of pollution comes from cars (automobile emissions) (if ${ }^{206} \mathrm{~Pb} /{ }^{207} \mathrm{~Pb}=1.1000-1.1400$ [automobile emissions]).

The obtained isotope ratio values are comparable with Avram et al., 2014 (1.1100 to 1.2000 Romania wines) and Almeida et al., 2016 (1.1440 to 1.1820 Brazilian wines).

The highest values of ${ }^{208} \mathrm{~Pb} /{ }^{206} \mathrm{~Pb}$ and ${ }^{206} \mathrm{~Pb} /{ }^{204} \mathrm{~Pb}$ were registered to wine obtained from Muscat Ottonel (2015) variety from Bujoru wine-growing center $(2.14190 \pm 0.00743$ ${ }^{208} \mathrm{~Pb} /{ }^{206} \mathrm{~Pb}$ ) and Cabernet Sauvignon (2014) variety from Oancea wine-growing center $\left(17.70857 \pm 0.00394[0.02238]{ }^{208} \mathrm{~Pb} /{ }^{206} \mathrm{~Pb}\right)$ while Cabernet Sauvignon (2014) from Oancea wine-growing center (2.09205 \pm 0.00576 ${ }^{208} \mathrm{~Pb} /{ }^{206} \mathrm{~Pb}$ ) and Feteasca Regala (2014) from Oancea wine-growing center (17.21089 \pm $0.00116{ }^{206} \mathrm{~Pb} /{ }^{204} \mathrm{~Pb}$ ) recorded the lowest isotope ration. The results are comparable with Almeida et al., 2016 (2.0700 to 2.1570 Brazilian wines ${ }^{208} \mathrm{~Pb} /{ }^{206} \mathrm{~Pb} ; 16.6670$ to 17.9960 Brazilian wines $\left.{ }^{204} \mathrm{~Pb} /{ }^{206} \mathrm{~Pb}\right)$ and also with Barbaste et al., 2002 (2.0990 to 2.1030 Italian wines ${ }^{208} \mathrm{~Pb} /{ }^{206} \mathrm{~Pb}$; 17.544 to 18.3210 Italian wines ${ }^{204} \mathrm{~Pb} /{ }^{206} \mathrm{~Pb}$ ).

The abundance of the lead isotopes ${ }^{204} \mathrm{~Pb}$ (non-radiogenic), $\quad{ }^{206} \mathrm{~Pb}, \quad{ }^{207} \mathrm{~Pb}$ and ${ }^{208} \mathrm{~Pb}$ (radiogenic) originated from the genesis of the substrate varies with geological ages. The original composition of the rock upon its formation and consequently, with geographical areas (Gulson et al., 1992), this property is useful in order to identify of the source of lead in a subjected wine sample provided that the measurements of the isotope ratio is precise and accurate. 
Concerning ${ }^{87} \mathrm{Sr} /{ }^{86} \mathrm{Sr}$ isotope ratio, the values are between the ranges from 0.70112 to 0.74275 with an average value of 0.71909 . The highest values were registered to wine obtained from Fetească neagră (2016) variety $(0.74275 \pm$ 0.00261) from Smulți wine-growing center, the lowest value of ${ }^{87} \mathrm{Sr} /{ }^{86} \mathrm{Sr}$ isotope ratio was recorded to wine obtained from Muscat Ottonel (2014) variety $(0.70165 \pm 0.00058)$ Oancea winegrowing center.

The values of ${ }^{87} \mathrm{Sr} /{ }^{86} \mathrm{Sr}$ isotope ratio obtained are comparable with Geana et al., 2017 (0.71015 to 0.72311 Romanian wines); Avram et al., 2014 (0.7600 to 0.9300$)$.

Variation of the ${ }^{206} \mathrm{~Pb} /{ }^{207} \mathrm{~Pb},{ }^{208} \mathrm{~Pb} /{ }^{206} \mathrm{~Pb}$, ${ }^{206} \mathrm{~Pb} /{ }^{204} \mathrm{~Pb},{ }^{87} \mathrm{Sr} /{ }^{86} \mathrm{Sr}$, isotope ratio and heavy metals concentration from wines with different geographical origins confirm the link with geological substratum of the production territory, making the ${ }^{206} \mathrm{~Pb} /{ }^{207} \mathrm{~Pb},{ }^{208} \mathrm{~Pb} /{ }^{206} \mathrm{~Pb}$, ${ }^{206} \mathrm{~Pb} /{ }^{204} \mathrm{~Pb},{ }^{87} \mathrm{Sr} /{ }^{86} \mathrm{Sr}$, isotope ration and heavy metals concentration a robust instrument for tracing the geographical provenance of wines.

\subsection{Combining multielement analysis and} ${ }^{206} \mathrm{~Pb} /{ }^{207} \mathrm{~Pb},{ }^{208} \mathrm{~Pb} /{ }^{206} \mathrm{~Pb},{ }^{206} \mathrm{~Pb} /{ }^{204} \mathrm{~Pb},{ }^{87} \mathrm{Sr} /{ }^{86} \mathrm{Sr}$, isotope ratio from wine samples for discrimination analysis

Multivariate techniques are methods of analysis generally recognized as very all know to study environmental problems (Tauler et al., 1995). From this kind of methods, Linear
Discriminant Analysis (LDA) has been selected one of the most advantageous to have a close look of our system. LDA belongs to supervised pattern recognition methods (Vončina, 2009) and has the aim to assign object to several predetermined classes.

Linear Discriminant Analysis (LDA) was used as a supervised learning technique for the differentiation of wines intro groups on the basis of grape variety and year of production and finding markers which showed a significant discrimination value (variables with Wilk's lambda near zero, $\mathrm{p}$ value $<0.05$ and higher $\mathrm{F}$ coefficients). Stepwise linear discriminant analysis (LDA) was used to identify significant tracers for classification to the geographical discrimination of the wines samples. Stepwise Discriminant Analysis (LDA) was used to designate suitable variables for classification of the samples, eliminating the variables that do not contribute to discrimination of the wine. In order to validate the proposed statistic model, based on variables which showed higher significance in first LDA assessment, we performed a second Linear Discriminant Analysis (LDA) for the test set consisting of wines used to build statistical model (training set) together with data from other wine samples that are not included in the first LDA (control-set).

Cross-validation was applied to determine the optimal number of variables required to obtain robust models.

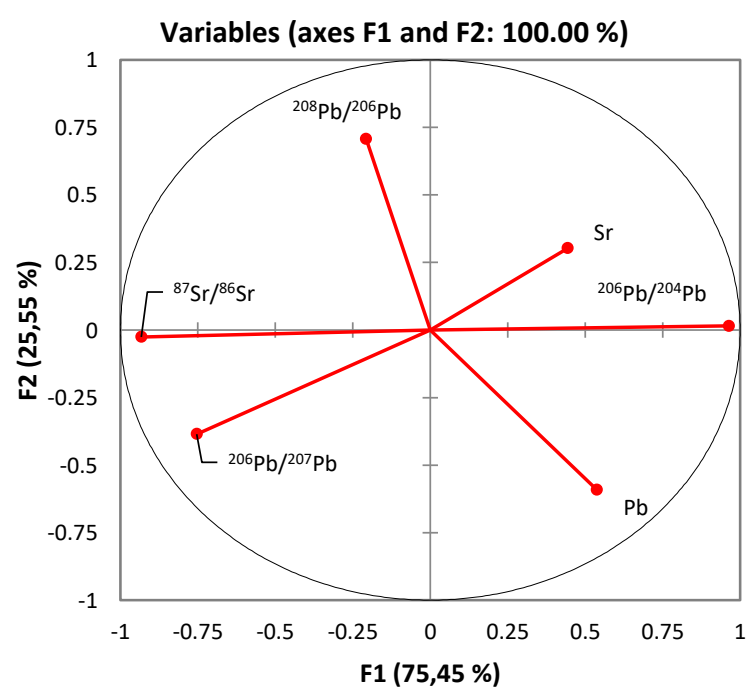


Figure 1. Correlation between analyzed parameters and the factors in discriminant analysis the origin of the wine

In this study, the content of certain wines shows high concentration of metals, but not exceeding the maximum recommended by International Organisation of Vine and Wine (O.I.V., 2015), and this mostly due to agricultural practices, fertilizers and technological winemaking processes.

Elements like $\mathrm{Pb}, \mathrm{Cu}, \mathrm{Ni}, \mathrm{Cd}, \mathrm{U}$ and $\mathrm{Hg}$ showed a high discriminatory power for geographic origin of Romanian wines, but additional new elements ( $\mathrm{Mn}, \mathrm{Cr})$ and ${ }^{207} \mathrm{~Pb} /{ }^{206} \mathrm{~Pb},{ }^{208} \mathrm{~Pb} /{ }^{206} \mathrm{~Pb},{ }^{204} \mathrm{~Pb} /{ }^{206} \mathrm{~Pb},{ }^{87} \mathrm{Sr} /{ }^{86} \mathrm{Sr}$ isotope ratio have been investigate in order to identify new tracers for geographical traceability of Romanian wines (Geana et al., 2017; Bora et al., 2016; Bora et al., 2018).

The wines obtained in the three winegrowing centers can be geographical fingerprints based on the concentration of $\mathrm{Pb}$,
$\mathrm{Cu}, \mathrm{Ni}, \mathrm{Cd}, \mathrm{Hg}, \mathrm{Mn}, \mathrm{Cr}, \mathrm{U}$ and also based on the ${ }^{207} \mathrm{~Pb} /{ }^{206} \mathrm{~Pb},{ }^{208} \mathrm{~Pb} /{ }^{206} \mathrm{~Pb},{ }^{204} \mathrm{~Pb} /{ }^{206} \mathrm{~Pb},{ }^{87} \mathrm{Sr} /{ }^{86} \mathrm{Sr}$ isotope ratio (Bora et al., 2016).

Based on the elemental contents and ${ }^{207} \mathrm{~Pb} /{ }^{206} \mathrm{~Pb},{ }^{208} \mathrm{~Pb} /{ }^{206} \mathrm{~Pb},{ }^{204} \mathrm{~Pb} /{ }^{206} \mathrm{~Pb},{ }^{87} \mathrm{Sr} /{ }^{86} \mathrm{Sr}$ isotope ratio, the cross-validation technique provided a $100 \%$ percentage of predicted membership according to the origin of the wine $(\mathrm{F} 1=75.45 \%$ and $\mathrm{F} 2=25.55 \%)$. The linear correction revealed acceptable scores for the two defined discriminant factors (F1 and F2) (Figure $1)$.

A significant differentiation of wines according to wine-growing centers and year of wine production was carried out for wines samples, which demonstrates the importance of elemental profile for the geographical traceability of wines (Figure 2).

Observations (axes F1 and F2: $100.00 \%$ )

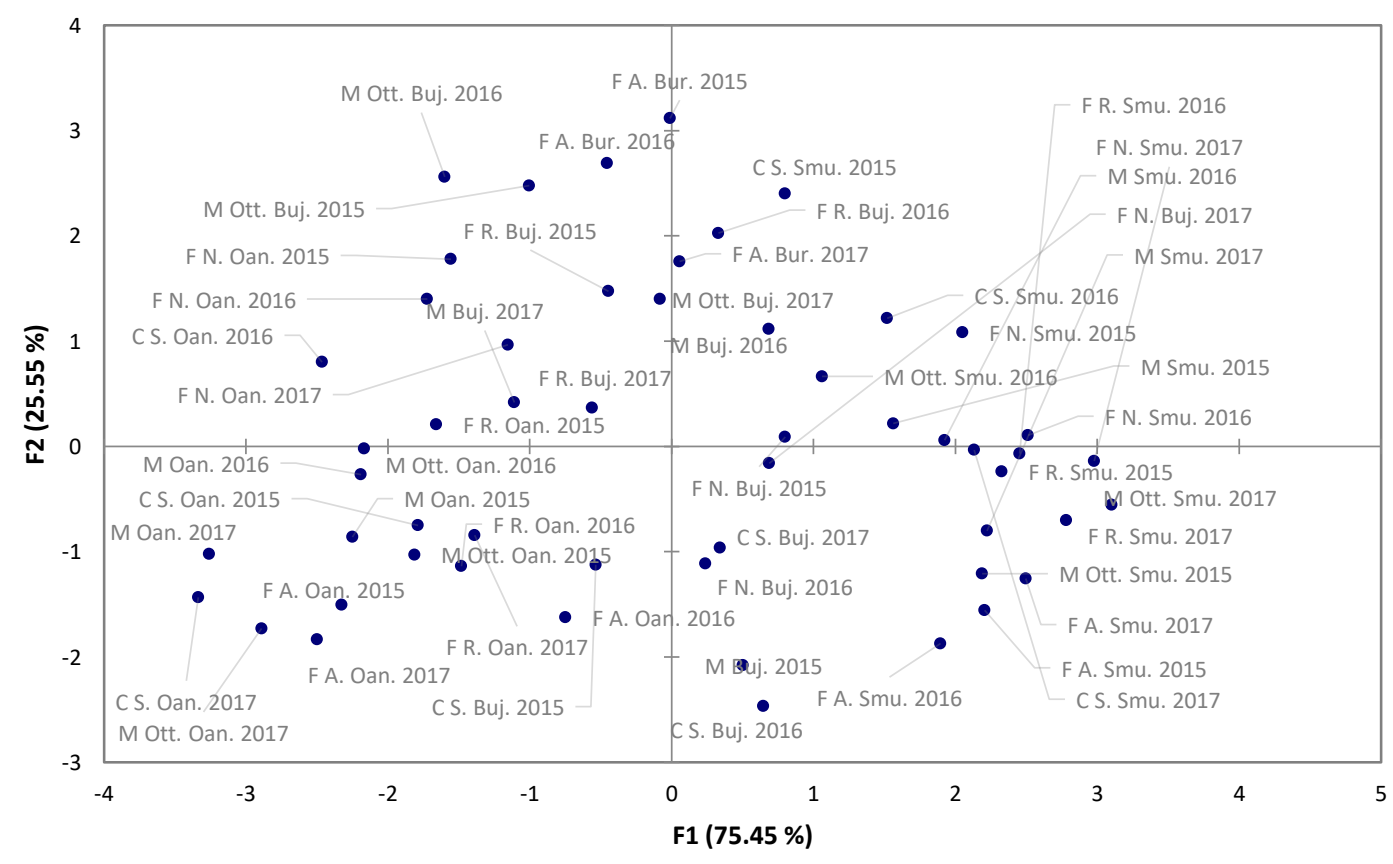

Figure 2. Differentiation of wines based on element contents and ${ }^{206} \mathrm{~Pb} /{ }^{207} \mathrm{~Pb},{ }^{208} \mathrm{~Pb} /{ }^{206} \mathrm{~Pb},{ }^{206} \mathrm{~Pb} /{ }^{204} \mathrm{~Pb}$, ${ }^{87} \mathrm{Sr} /{ }^{86} \mathrm{Sr}$ isotope ratios 
Table 4. The analysis of the main quality parameters in wine samples from Dealu Bujorului Vineyard

\begin{tabular}{|c|c|c|c|c|c|c|c|c|c|c|c|c|}
\hline 茪 & 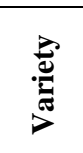 & ప્خ & $\begin{array}{l}\text { Alcohol } \\
\text { (\% vol.) }\end{array}$ & $\begin{array}{l}\text { Total acidity } \\
\left.\text { (g/L } \mathrm{C}_{4} \mathrm{H}_{4} \mathrm{O}_{6}\right)\end{array}$ & $\begin{array}{c}\text { Volatile } \\
\text { acidity } \\
\text { (g/L } \\
\left.\mathrm{CH}_{3} \mathrm{COOH}\right)\end{array}$ & $\begin{array}{c}\text { Residual } \\
\text { Sugar } \\
(\mathrm{g} / \mathrm{L})\end{array}$ & $\begin{array}{c}\text { Non } \\
\text { reducing } \\
\text { extract } \\
(\mathrm{g} / \mathrm{L})\end{array}$ & $\begin{array}{l}\text { Acetic acid } \\
(\mathrm{g} / \mathrm{L})\end{array}$ & $\underset{(\mathrm{mg} / \mathrm{L})}{\operatorname{Amino} \text { acid }}$ & $\begin{array}{c}\text { Tartaric } \\
\text { acid } \\
(\mathrm{g} / \mathrm{L})\end{array}$ & $\begin{array}{c}\text { L-Malic acid } \\
(\mathrm{g} / \mathrm{L})\end{array}$ & $\begin{array}{c}\text { L-Lactic acid } \\
(\mathrm{g} / \mathrm{L})\end{array}$ \\
\hline \multirow{18}{*}{ 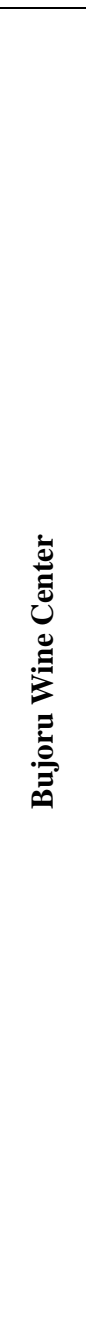 } & \multirow{3}{*}{$\begin{array}{c}\text { M } \\
\text { Ott. }\end{array}$} & 2014 & $\begin{array}{c}14.46 \pm 0.12 \\
\text { abcde }\end{array}$ & $\underset{\text { Imnop }}{4.68 \pm 0.10}$ & $\underset{\text { mnop }}{0.32 \pm 0.04}$ & $6.47 \pm 0.25$ & $\begin{array}{c}24.75 \pm 0.53 \\
\text { cdefg }\end{array}$ & $0.33 \pm 0.01 \mathrm{ab}$ & $22.52 \pm 0.95$ & $1.29 \underset{\mathrm{jkl}}{ \pm 0.05}$ & $1.12 \pm 0.10^{\mathrm{i}}$ & ULD \\
\hline & & 2015 & $\begin{array}{c}14.41 \pm 0.45 \\
\text { abcdef }\end{array}$ & $\begin{array}{c}4.91 \pm 0.06 \\
\text { iìjkl }\end{array}$ & $\begin{array}{c}0.46 \pm 0.03 \\
\text { cdefghiijkl }\end{array}$ & $\begin{array}{c}4.59 \pm 0.07 \\
\text { opqrsșt }\end{array}$ & $\underset{\text { hiî̀jk }}{21.88 \pm 0.76}$ & $0.34 \pm 0.05^{\mathrm{ab}}$ & $\begin{array}{c}17.37 \pm 3.44 \\
\text { efghiîjklmnop }\end{array}$ & $1.34 \underset{\mathrm{jkl}}{ \pm 0.12}$ & $1.23 \pm 0.12^{\mathrm{i}}$ & ULD \\
\hline & & 2016 & $\begin{array}{c}13.89 \pm 0.59 \\
\text { cdefghî̂ }\end{array}$ & $\begin{array}{c}4.70 \pm 0.07 \\
\text { Imnop }\end{array}$ & $\begin{array}{c}0.50 \pm 0.03 \\
\text { bcdefgh }\end{array}$ & $11.19 \pm 0.75$ & $\underset{\text { fghiîjk }}{22.45 \pm 1.00}$ & $0.31 \pm \underset{\mathrm{abc}}{0.02}$ & $23.03 \pm 1.53^{\mathrm{a}}$ & $\begin{array}{c}1.67 \pm 0.19 \\
\text { efghiîjkl }\end{array}$ & $2.07 \pm 0.08 \mathrm{abcd}$ & ULD \\
\hline & \multirow{3}{*}{ F A. } & 2014 & $\begin{array}{c}13.26 \pm 0.34 \\
\text { fghiîjklmno }\end{array}$ & $5.31 \pm 0.31$ & $\begin{array}{c}0.46 \pm 0.08 \\
\text { cdehiijkl }\end{array}$ & $3.63 \pm 0.17$ ștt & $\underset{\text { hiîjk }}{21.81 \pm 0.84}$ & $0.34 \pm 0.11^{\mathrm{ab}}$ & $22.10 \pm 0.95^{\mathrm{a}}$ & $\begin{array}{c}1.59 \pm 0.63 \\
\text { ghiî̀jkl }\end{array}$ & $1.18 \pm 0.08^{\mathrm{i}}$ & ULD \\
\hline & & 2015 & $\begin{array}{c}13.11 \pm 0.59 \\
\text { hiîjklmno }\end{array}$ & $\underset{\text { fghi }}{5.25 \pm 0.06}$ & $\begin{array}{c}0.54 \pm 0.03 \\
\text { abcd }\end{array}$ & 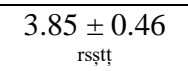 & $\underset{\text { ghiîjk }}{22.86 \pm 1.03}$ & $0.30 \pm \underset{\mathrm{abc}}{0.02}$ & $23.04 \pm 1.53^{\mathrm{a}}$ & $1.19 \pm 0.07^{1}$ & $1.12 \pm 0.10^{\mathrm{i}}$ & ULD \\
\hline & & 2016 & $\begin{array}{c}14.39 \pm 0.47 \\
\text { abcdefg }\end{array}$ & $\begin{array}{c}5.41 \pm 0.42 \\
\text { defgh }\end{array}$ & $\begin{array}{c}0.46 \pm 0.03 \\
\text { cdefghiijkl }\end{array}$ & $\begin{array}{c}5.03 \pm 0.43 \\
\text { nopqrs }\end{array}$ & $20.11_{\mathrm{k}} \pm 1.13$ & $\begin{array}{c}0.19 \pm 0.05 \\
\text { efghiijkklmno }\end{array}$ & $\begin{array}{c}20.96 \pm 1.57 \\
\text { abcdefg }\end{array}$ & $\underset{\text { cdefghi }}{2.14 \pm 0.23}$ & $1.23 \pm 0.01^{\mathrm{i}}$ & ULD \\
\hline & \multirow{3}{*}{ F R. } & 2014 & $\begin{array}{c}13.59 \pm 0.26 \\
\text { cdefghiijk }\end{array}$ & $\begin{array}{c}4.55 \pm 0.02 \\
\text { mnop }\end{array}$ & $0.60 \pm 0.06^{\mathrm{ab}}$ & $\begin{array}{c}5.51 \pm 0.33 \\
\text { jklmnopq }\end{array}$ & $\underset{\text { ghiîjk }}{22.56 \pm 1.13}$ & $\underset{\text { mnopq }}{0.12 \pm 0.02}$ & $13.13 \pm 1.58^{\mathrm{rs}}$ & $\begin{array}{c}2.33 \pm 0.01 \\
\text { bcdef }\end{array}$ & $1.22 \pm 0.11^{\mathrm{i}}$ & ULD \\
\hline & & 2015 & $\begin{array}{c}14.03 \pm 0.55 \\
\text { cdefghi }\end{array}$ & $4.36 \pm 0.15^{\mathrm{p}}$ & $0.61 \pm 0.05^{\mathrm{a}}$ & $2.45 \pm 0.19 t$ & $20.96 \pm 1.33$ & $\begin{array}{c}0.12 \pm 0.03 \\
\text { nopq }\end{array}$ & $\begin{array}{c}19.77 \pm 1.37 \\
\text { abcdefghiîj }\end{array}$ & $\begin{array}{c}1.77 \pm 0.48 \\
\text { efghiîjkl }\end{array}$ & $1.34 \pm 0.12$ fghi & ULD \\
\hline & & 2016 & $\begin{array}{c}12.76 \pm 0.91 \\
\text { îjklmnop }\end{array}$ & $\begin{array}{c}4.48 \pm 0.36 \\
\text { nop }\end{array}$ & $\begin{array}{c}0.52 \pm 0.04 \\
\text { abcde }\end{array}$ & $3.25 \pm 0.04 \mathrm{tt}$ & $\begin{array}{c}20.15 \pm 1.18 \\
\mathrm{k}\end{array}$ & $\begin{array}{c}0.19 \pm 0.02 \\
\text { efghiijklmno }\end{array}$ & $\underset{\text { abcdefgh }}{20.84 \pm 1.66}$ & $1.37 \pm 0.07$ & $1.07 \pm 0.04^{\mathrm{i}}$ & ULD \\
\hline & \multirow{3}{*}{ F N. } & 2014 & $\underset{\text { abcd }}{14.55 \pm 0.23}$ & $\begin{array}{c}5.33 \pm 0.02 \\
\text { efgh }\end{array}$ & $\begin{array}{c}0.43 \pm 0.04 \\
\text { defghiijklm }\end{array}$ & $0.30 \pm 0.06^{\mathrm{u}}$ & $\underset{\text { abcde }}{26.22 \pm 0.63}$ & $\begin{array}{c}0.18 \pm 0.05 \\
\text { ghiîjklmnop }\end{array}$ & $\underset{\mathrm{ab}}{22.26 \pm 1.71}$ & $\underset{\text { fghiijkl }}{1.62 \pm 0.26}$ & $1.92 \pm 0.23$ abcdefg & ULD \\
\hline & & 2015 & $15.17 \pm 0.53^{a b}$ & $\begin{array}{c}5.43 \pm 0.21 \\
\text { defgh }\end{array}$ & $\begin{array}{c}0.42 \pm 0.06 \\
\text { defghiijkklmn }\end{array}$ & $3.63 \pm 0.62$ ștt & $\underset{\text { ghiîjk }}{22.11 \pm 1.16}$ & $0.36 \pm 0.05^{\mathrm{a}}$ & $\begin{array}{c}20.81 \pm 0.80 \\
\text { abcdefgh }\end{array}$ & $1.37 \pm 0.05$ & $1.30 \pm 0.12 \mathrm{ghi}$ & ULD \\
\hline & & 2016 & $\underset{\mathrm{abc}}{14.73 \pm 1.00}$ & $\underset{\text { fghi }}{5.25 \pm 0.06}$ & $\begin{array}{c}0.48 \pm 0.05 \\
\text { cdefghiîj }\end{array}$ & $3.76 \underset{\text { sștt }}{ \pm 0.33}$ & $\underset{\text { hiîjk }}{21.68 \pm 1.67}$ & $\underset{\text { defghijkl }}{0.21 \pm 0.03}$ & $\begin{array}{c}17.45 \pm 3.38 \\
\text { efghiîjklmnop }\end{array}$ & $\underset{\text { cdefghî̀jk }}{2.04 \pm 0.13}$ & $1.28 \pm 0.06^{\mathrm{ghi}}$ & ULD \\
\hline & \multirow{3}{*}{$\mathbf{M}$} & 2014 & $\begin{array}{c}14.52 \pm 0.27 \\
\text { abcde }\end{array}$ & $\begin{array}{c}4.83 \pm 0.13 \\
\text { klmn }\end{array}$ & $0.31 \pm 0.03^{\text {op }}$ & $3.59 \pm 0.35$ șț & $\begin{array}{c}27.19 \pm 1.40 \\
\mathrm{a}\end{array}$ & $\begin{array}{c}0.31 \pm 0.09 \\
\text { abc }\end{array}$ & $\begin{array}{c}13.89 \pm 3.78 \\
\text { pqrs }\end{array}$ & $1.27 \pm 0.06^{1}$ & $1.21 \pm 0.11^{\mathrm{i}}$ & ULD \\
\hline & & 2015 & $15.40 \pm 0.63^{a}$ & $5.31 \pm 0.11$ & $\begin{array}{l}0.41 \pm 0.03 \\
\text { efghiî̀jklmno }\end{array}$ & $6.60 \pm 1.08$ & $\begin{array}{c}24.33 \pm 1.12 \\
\text { defgh }\end{array}$ & $\begin{array}{c}0.16 \pm 0.05 \\
\text { klmnopq }\end{array}$ & $\begin{array}{c}18.23 \pm 2.70 \\
\text { cdefghiîjklmn }\end{array}$ & $1.23 \pm 0.12^{1}$ & $1.29 \pm 0.12 \mathrm{ghi}$ & ULD \\
\hline & & 2016 & $15.44 \pm 0.48^{a}$ & $\begin{array}{c}4.66 \pm 0.18 \\
\text { Imnop }\end{array}$ & $\underset{\text { abcdef }}{0.52 \pm 0.04}$ & $6.65 \pm 0.59$ 1̂jk & $\underset{\text { hiîjk }}{21.69 \pm 0.67}$ & $\begin{array}{c}0.18 \pm 0.02 \\
\text { fghiijklmnop }\end{array}$ & $\begin{array}{c}17.08 \pm 3.66 \\
\text { ghiîjklmnopq }\end{array}$ & $\begin{array}{c}1.78 \pm 0.19 \\
\text { efghiîjkl }\end{array}$ & $1.22 \pm 0.01^{\mathrm{i}}$ & ULD \\
\hline & \multirow{3}{*}{ C S. } & 2014 & $\begin{array}{c}13.47 \pm 0.54 \\
\text { defghiîjklmn }\end{array}$ & $5.29 \pm 0.06^{\text {fgh }}$ & $\begin{array}{c}0.50 \pm 0.06 \\
\text { bcdefgh }\end{array}$ & $3.59 \pm 1.33 \mathrm{stth}$ & $\underset{\text { abcde }}{26.18 \pm 1.46}$ & $\begin{array}{c}0.16 \pm 0.04 \\
\text { îjklmnopq }\end{array}$ & $\underset{\mathrm{ab}}{22.36 \pm 1.88}$ & $\begin{array}{c}2.06 \pm 0.16 \\
\text { cdefghiî }\end{array}$ & $1.23 \pm 0.01^{\mathrm{i}}$ & ULD \\
\hline & & 2015 & $\begin{array}{c}13.00 \pm 0.46 \\
\text { giîjklmnop }\end{array}$ & $\begin{array}{c}4.67 \pm 0.12 \\
\text { Imnop }\end{array}$ & $\begin{array}{c}0.50 \pm 0.04 \\
\text { bedefghi }\end{array}$ & $\underset{\text { pqrșst }}{4.37 \pm 1.67}$ & $\underset{\text { fghiî̀jk }}{22.45 \pm 0.95}$ & $\underset{\text { nopq }}{0.12 \pm 0.01}$ & $\underset{\text { abcd }}{21.40 \pm 0.46}$ & $\underset{\text { efghiîjkl }}{1.78 \pm 0.19}$ & $1.29 \pm 0.12 \mathrm{ghi}$ & ULD \\
\hline & & 2016 & $\underset{\text { cdefghiîj }}{13.76 \pm 0.85}$ & $\begin{array}{c}5.32 \pm 0.11 \\
\text { efgh }\end{array}$ & $\begin{array}{c}0.45 \pm 0.03 \\
\text { cdefghiijkl }\end{array}$ & $\begin{array}{c}5.67 \pm 0.49 \\
\text { jklmnop }\end{array}$ & $\underset{\text { fghiîj }}{23.40 \pm 1.79}$ & $0.31 \pm \underset{\mathrm{abc}}{0.03}$ & $\underset{\text { abcd }}{21.52 \pm 1.80}$ & $\begin{array}{c}2.06 \pm 0.15 \\
\text { cdefghiî }\end{array}$ & $1.92 \pm 0.56^{\text {abcdefg }}$ & ULD \\
\hline
\end{tabular}


Bora /Carpathian Journal of Food Science and Technology 2019,11(3), 121-139

\begin{tabular}{|c|c|c|c|c|c|c|c|c|c|c|c|c|}
\hline 晜 & $\frac{\overrightarrow{0}}{\sqrt[0]{*}}$ & $\dot{\nexists}$ & $\begin{array}{l}\text { Alcohol } \\
\text { (\% vol.) }\end{array}$ & $\begin{array}{l}\text { Total acidity } \\
\left(\mathrm{g} / \mathrm{L} \mathrm{C}_{4} \mathrm{H}_{4} \mathrm{O}_{6}\right)\end{array}$ & $\begin{array}{c}\text { Volatile } \\
\text { acidity } \\
\text { (g/L } \\
\left.\mathrm{CH}_{3} \mathrm{COOH}\right)\end{array}$ & $\begin{array}{c}\text { Residual } \\
\text { Sugar } \\
(\mathrm{g} / \mathrm{L})\end{array}$ & $\begin{array}{c}\text { Non } \\
\text { reducing } \\
\text { extract } \\
(\mathrm{g} / \mathrm{L})\end{array}$ & $\begin{array}{l}\text { Acetic acid } \\
(\mathrm{g} / \mathrm{L})\end{array}$ & $\begin{array}{l}\text { Amino acid } \\
(\mathrm{mg} / \mathrm{L})\end{array}$ & $\begin{array}{c}\text { Tartaric } \\
\text { acid } \\
(\mathrm{g} / \mathrm{L})\end{array}$ & $\begin{array}{l}\text { L-Malic acid } \\
(\mathrm{g} / \mathrm{L})\end{array}$ & $\begin{array}{l}\text { L-Lactic acid } \\
(\mathrm{g} / \mathrm{L})\end{array}$ \\
\hline \multirow{18}{*}{ 离 } & \multirow{3}{*}{$\begin{array}{c}\text { M } \\
\text { Ott. }\end{array}$} & 2014 & $\begin{array}{c}13.52 \pm 0.51 \\
\text { defghiîjkl }\end{array}$ & $\begin{array}{c}4.48 \pm 0.12 \\
\text { nop }\end{array}$ & $\begin{array}{c}0.52 \pm 0.03 \\
\text { abcdef }\end{array}$ & $\begin{array}{c}10.78 \pm 0.51 \\
\mathrm{ab}\end{array}$ & $\begin{array}{c}22.41 \pm 1.05 \\
\text { fghiijjk }\end{array}$ & $\begin{array}{c}0.24 \pm 0.07 \\
\text { cdefghiî }\end{array}$ & $9.61 \pm 2.45$ s & $1.23 \pm 0.12^{1}$ & $1.29 \pm 0.12 \mathrm{ghi}$ & ULD \\
\hline & & 2015 & $\underset{\text { opqrs }}{11.88 \pm 0.90}$ & $\underset{\text { nop }}{4.51 \pm 0.18}$ & $\begin{array}{c}0.46 \pm 0.03 \\
\text { cdefghiijkl }\end{array}$ & $\underset{\text { ghiî }}{7.55}$ & $\underset{\text { fghiîj }}{23.22 \pm 1.52}$ & $\underset{\text { defghiîjklmn }}{0.20 \pm 0.02}$ & $12.96 \pm 1.10^{\mathrm{rs}}$ & $1.34 \underset{\mathrm{jkl}}{ \pm 0.12}$ & $1.23 \pm 0.01^{\mathrm{i}}$ & ULD \\
\hline & & 2016 & $\begin{array}{c}13.36 \pm 0.43 \\
\text { efghiijjklmno }\end{array}$ & $\begin{array}{c}5.08 \pm 0.06 \\
\text { hiîjk }\end{array}$ & 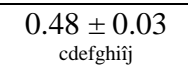 & $\begin{array}{c}8.87 \pm 1.12 \\
\text { defg }\end{array}$ & $\underset{\text { ghiijkk }}{22.78 \pm 1.41}$ & $0.09 \pm \underset{\mathrm{pq}}{0.03}$ & $\begin{array}{c}16.21 \pm 1.70 \\
\text { îjklmnopqr }\end{array}$ & $\begin{array}{c}2.19 \pm 0.26 \\
\text { cdefgh }\end{array}$ & $2.28 \pm 0.10^{\mathrm{abc}}$ & ULD \\
\hline & \multirow{3}{*}{ F A. } & 2014 & $\underset{\text { mnopqr }}{12.28 \pm 0.74}$ & $\begin{array}{c}4.73 \pm 0.06 \\
\text { Imop }\end{array}$ & $\begin{array}{c}0.56 \pm 0.15 \\
\text { abc }\end{array}$ & $\begin{array}{c}7.48 \pm 0.79 \\
\text { ghiî̀ }\end{array}$ & $\underset{\text { abcd }}{26.60 \pm 2.02}$ & $\begin{array}{c}0.16 \pm 0.04 \\
\text { ijklmnop }\end{array}$ & $\begin{array}{c}19.34 \pm 1.71 \\
\text { abcdefghiijjk }\end{array}$ & $\begin{array}{c}1.70 \pm 0.13 \\
\text { efghiijjkl }\end{array}$ & $2.26 \pm 0.12 \mathrm{abcd}$ & ULD \\
\hline & & 2015 & $\underset{\substack{12.33 \pm 0.44 \\
\text { lmnopqr }}}{1}$ & $\begin{array}{c}4.64 \pm 0.27 \\
\text { Imnop }\end{array}$ & $\begin{array}{c}0.49 \pm 0.03 \\
\text { cdefghiîj }\end{array}$ & $\begin{array}{c}11.37 \pm 0.96 \\
\mathrm{a}\end{array}$ & $\begin{array}{c}27.88 \pm 1.25 \\
a\end{array}$ & $\begin{array}{c}0.14 \pm 0.03 \\
\text { Imnopq }\end{array}$ & $\begin{array}{c}18.11 \pm 0.49 \\
\text { defghiîjklmno }\end{array}$ & $1.44 \pm 0.11$ & $2.07 \pm 0.55$ abcd & ULD \\
\hline & & 2016 & $\begin{array}{c}13.22 \pm 0.43 \\
\text { ghiîjklmno }\end{array}$ & $\begin{array}{c}4.59 \pm 0.23 \\
\text { Imnop }\end{array}$ & $\begin{array}{c}0.47 \pm 0.04 \\
\text { cdefghiîjk }\end{array}$ & $\underset{\mathrm{abc}}{10.06 \pm 0.14}$ & $23.45 \pm \underset{\text { fghiîj }}{2} 1.11$ & $\begin{array}{c}0.17 \pm 0.05 \\
\text { hiîjklmnop }\end{array}$ & $22.99 \pm 2.13^{a}$ & $2.93 \pm 0.0 .22$ & $1.37 \pm 0.17^{\text {efghi }}$ & ULD \\
\hline & \multirow{3}{*}{ F R. } & 2014 & $\underset{\mathrm{qrs}}{11.52 \pm 0.34}$ & $\underset{\text { ghiîj }}{5.18 \pm 0.11}$ & $\begin{array}{c}0.45 \pm 0.02 \\
\text { cdefghiìjkl }\end{array}$ & $\begin{array}{c}8.95 \pm 0.95 \\
\text { cdef }\end{array}$ & $\underset{\substack{\mathrm{i} j \mathrm{k} \\
21.20 \pm 1.00}}{ }$ & $\underset{\text { abcd }}{0.28 \pm 0.05}$ & $\underset{\mathrm{qrs}}{13.40 \pm 1.08}$ & $1.44 \pm 0.47$ & $1.06 \pm 0.14^{\mathrm{i}}$ & ULD \\
\hline & & 2015 & $11.07 \pm 0.17^{\mathrm{s}}$ & $\underset{\text { fghi }}{5.26 \pm 0.05}$ & $\begin{array}{c}0.36 \pm 0.03 \\
\text { klmnop }\end{array}$ & $\begin{array}{c}5.36 \pm 0.12 \\
\text { klmnopq }\end{array}$ & $\underset{\text { ghiîjk }}{22.08 \pm 1.59}$ & $\begin{array}{c}0.18 \pm 0.05 \\
\text { ghiîjklmnop }\end{array}$ & 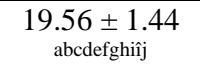 & $\underset{\text { defghiîjkl }}{1.88 \pm 0.45}$ & $1.27 \pm 0.06^{\mathrm{hi}}$ & ULD \\
\hline & & 2016 & $\underset{\text { nopqrs }}{12.18 \pm 0.37}$ & $\begin{array}{c}5.15 \pm 0.07 \\
\text { ghiijjk }\end{array}$ & $\begin{array}{c}0.42 \pm 0.09 \\
\text { defghiijjklmn }\end{array}$ & $\underset{\text { abcd }}{10.01 \pm 1.00}$ & $\underset{\text { hiîjk }}{21.18 \pm 1.98}$ & $\begin{array}{c}0.24 \pm 0.04 \\
\text { cdefghiî }\end{array}$ & $\begin{array}{c}19.47 \pm 1.99 \\
\text { abcdefghiîjk }\end{array}$ & $\begin{array}{c}1.48 \pm 0.17 \\
\text { hiijjkl }\end{array}$ & $2.12 \pm 0.02^{a b c d}$ & ULD \\
\hline & \multirow{3}{*}{ F N. } & 2014 & $\begin{array}{c}14.15 \pm 0.78 \\
\text { bcdefgh }\end{array}$ & $\begin{array}{c}5.74 \underset{\text { bcd }}{ \pm 0} 0.07 \\
\end{array}$ & $\begin{array}{c}0.50 \pm 0.06 \\
\text { bcdefghi }\end{array}$ & $\begin{array}{c}11.04 \pm 0.51 \\
\mathrm{a}\end{array}$ & $\begin{array}{c}23.01 \pm 2.08 \\
\text { fghiîj }\end{array}$ & $\underset{\substack{0.15 \pm 0.06 \\
\text { jklmnopq }}}{0.06}$ & $\begin{array}{c}17.17 \pm 1.65 \\
\text { fghinjklmnopq }\end{array}$ & $\begin{array}{c}2.65 \pm 0.33 \\
\mathrm{abc}\end{array}$ & $2.52 \pm 0.52^{a b}$ & ULD \\
\hline & & 2015 & $\begin{array}{c}12.96 \pm 0.63 \\
\text { hiijjklmnop }\end{array}$ & $5.29 \pm 0.13^{\text {fgh }}$ & $\begin{array}{c}0.33 \pm 0.04 \\
\text { Imnop }\end{array}$ & $\underset{\text { fghi }}{8.08 \pm 1.32}$ & $\begin{array}{c}28.76 \pm 0.19 \\
\text { a }\end{array}$ & $0.10 \pm 0.01^{q}$ & $\begin{array}{c}17.40 \pm 0.65 \\
\text { efghiijklmnop }\end{array}$ & $\begin{array}{c}1.60 \pm 0.25 \\
\text { ghiijkl }\end{array}$ & $2.00 \pm 0.67 \mathrm{abcd}$ & ULD \\
\hline & & 2016 & $\begin{array}{c}13.08 \pm 0.58 \\
\text { hiîjklmno }\end{array}$ & $\underset{\text { ghiijj }}{5.17 \pm 0.04}$ & $\begin{array}{c}0.45 \pm 0.07 \\
\text { cdefghiîjkl }\end{array}$ & $\begin{array}{c}6.26 \pm 0.93 \\
\text { îjklmn }\end{array}$ & $\underset{\text { ghiîjk }}{22.71 \pm 1.51}$ & $\underset{\text { defghiîjjkl }}{0.21 \pm 0.02}$ & $\begin{array}{c}21.10 \pm 2.01 \\
\text { abcdef }\end{array}$ & $\underset{\text { cdefghi }}{2.12 \pm 0.01}$ & $2.13 \pm 0.03 \mathrm{abcd}$ & ULD \\
\hline & \multirow{3}{*}{ M } & 2014 & $\begin{array}{c}13.10 \pm 0.58 \\
\text { hiîjklmno }\end{array}$ & $5.25 \pm 0.06$ & $\begin{array}{c}0.37 \pm 0.02 \\
\text { jklmnop }\end{array}$ & $\underset{\text { qrsșt }}{4.19 \pm 0.29}$ & $\underset{\text { hiîjk }}{21.52 \pm 1.80}$ & $\begin{array}{c}0.26 \pm 0.06 \\
\text { bcdefgh }\end{array}$ & $\underset{\text { abcdef }}{21.08 \pm 1.12}$ & $1.33 \pm 0.01^{\mathrm{kl}}$ & $1.29 \pm 0.12 \mathrm{ghi}$ & ULD \\
\hline & & 2015 & $\underset{\text { cdefghiî }}{13.95 \pm 0.52}$ & $\underset{\substack{\text { îkklm } \\
4.88 \pm 0.10}}{0.0}$ & $\begin{array}{c}0.38 \pm 0.06 \\
\text { îjklmnop }\end{array}$ & $6.85 \pm 0.60$ iîj & $\underset{\text { ghiîjk }}{22.49 \pm 2.09}$ & $\begin{array}{c}0.28 \pm 0.05 \\
\text { abcde }\end{array}$ & $\underset{\text { abcde }}{21.19 \pm 1.23}$ & $\begin{array}{c}2.49 \pm 0.25 \\
\text { bcd }\end{array}$ & $1.26 \pm 0.06^{\mathrm{hi}}$ & ULD \\
\hline & & 2016 & $\underset{\text { cdefghi }}{14.03 \pm 0.43}$ & $4.48 \pm 0.32^{\mathrm{op}}$ & $\begin{array}{c}0.40 \pm 0.06 \\
\text { ghiîjklmnop }\end{array}$ & $8.29 \pm 0.54$ & $\begin{array}{c}21.22 \pm 0.23 \\
\text { hiîjk }\end{array}$ & $\underset{\text { defghiîjkl }}{0.21 \pm 0.02}$ & $\underset{\text { abcdefghiî }}{20.13 \pm 1.41}$ & $\begin{array}{c}1.37 \pm 0.16 \\
\substack{\mathrm{ijk} k \mathrm{k} \\
0}\end{array}$ & $1.22 \pm 0.01^{\mathrm{i}}$ & ULD \\
\hline & \multirow{3}{*}{ C S. } & 2014 & $\underset{\mathrm{pqrs}}{11.74 \pm 0.31}$ & $5.38 \underset{\text { efgh }}{ \pm 0.28}$ & $0.31 \pm 0.03^{\circ p}$ & $3.74 \underset{\text { sșțt }}{ \pm 0.52}$ & $\begin{array}{c}27.95 \pm 1.00 \\
\mathrm{a}\end{array}$ & $\underset{\text { defghiijjklmn }}{0.20 \pm 0.02}$ & $\underset{\text { abcdefghiî }}{19.92 \pm 1.28}$ & $\underset{\text { defghiîjkl }}{1.85 \pm 0.44}$ & $2.56 \pm 0.58^{a}$ & ULD \\
\hline & & 2015 & $\begin{array}{c}13.07 \pm 0.84 \\
\text { hiijjklmno }\end{array}$ & $\begin{array}{c}5.18 \pm 0.06 \\
\text { ghiîj }\end{array}$ & $\begin{array}{c}0.34 \pm 0.01 \\
\text { Imnop }\end{array}$ & $\begin{array}{c}5.22 \pm 0.58 \\
\text { Imnopqr }\end{array}$ & $\begin{array}{c}27.63 \pm 1.03 \\
\mathrm{ab}\end{array}$ & $\begin{array}{c}0.21 \pm 0.02 \\
\text { defghiîjkl }\end{array}$ & $\begin{array}{c}16.62 \pm 2.00 \\
\text { hiîjklmnopqr }\end{array}$ & $1.34 \underset{j \mathrm{kl}}{ \pm 0.11}$ & $1.29 \pm 0.11 \mathrm{ghi}$ & ULD \\
\hline & & 2016 & $12.03 \pm 0.34$ & $\underset{\text { ghiî }}{5.22 \pm 0.01}$ & $\begin{array}{c}0.44 \pm 0.01 \\
\text { defghiîjklm }\end{array}$ & $\begin{array}{c}6.51 \pm 0.84 \\
\text { îjklm }\end{array}$ & $\begin{array}{c}21.34 \pm 1.00 \\
\text { hiîjk }\end{array}$ & $\begin{array}{c}0.16 \pm 0.03 \\
\text { îjklmnopq }\end{array}$ & $\underset{\text { opqrs }}{14.32 \pm 2.21}$ & $\begin{array}{c}2.37 \pm 0.07 \\
\text { bcde }\end{array}$ & $2.19 \pm 0.13^{a b c d}$ & ULD \\
\hline \multirow{2}{*}{ 冚 } & \multirow{2}{*}{$\begin{array}{c}\text { M } \\
\text { Ott. }\end{array}$} & 2014 & $\underset{\text { nopqrs }}{12.18 \pm 0.64}$ & $6.37 \pm 0.16^{\mathrm{a}}$ & $\begin{array}{c}0.47 \pm 0.02 \\
\text { cdefghiijjk }\end{array}$ & $3.28 \pm 0.36$ stt & $\underset{\text { ghiijkk }}{22.00 \pm 2.11}$ & $\begin{array}{c}0.16 \pm 0.07 \\
\text { îjklmnopq }\end{array}$ & $2.66 \pm 1.52^{t}$ & $\begin{array}{c}1.70 \pm 0.56 \\
\text { efghiîjkl }\end{array}$ & $1.34 \pm 0.10^{\text {fghi }}$ & ULD \\
\hline & & 2015 & $\underset{\text { qrs }}{11.52 \pm 0.34}$ & $\begin{array}{c}5.44 \pm 0.18 \\
\text { defgh }\end{array}$ & $\begin{array}{c}0.50 \pm 0.06 \\
\text { bcdefgh }\end{array}$ & $3.60 \pm 0.17$ stt & $\underset{\text { fghiîj }}{23.45 \pm 2.21}$ & $\begin{array}{c}0.20 \pm 0.02 \\
\text { defghiijiklmn }\end{array}$ & $10.81 \pm 1.33$ & $\begin{array}{c}1.71 \pm 0.55 \\
\text { efghiijjkl }\end{array}$ & $1.26 \pm 0.07 \mathrm{hi}$ & ULD \\
\hline
\end{tabular}




\begin{tabular}{|c|c|c|c|c|c|c|c|c|c|c|c|c|}
\hline Uั & 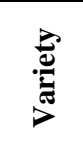 & $\stackrel{\varpi}{\nexists}$ & $\begin{array}{l}\text { Alcohol } \\
\text { (\% vol.) }\end{array}$ & $\begin{array}{l}\text { Total acidity } \\
\left(\mathrm{g} / \mathrm{L} \mathrm{C}_{4} \mathrm{H}_{4} \mathrm{O}_{6}\right)\end{array}$ & $\begin{array}{c}\text { Volatile } \\
\text { acidity } \\
\text { (g/L } \\
\left.\mathrm{CH}_{3} \mathrm{COOH}\right)\end{array}$ & $\begin{array}{l}\text { Residual } \\
\text { Sugar } \\
\text { (g/L) }\end{array}$ & $\begin{array}{c}\text { Non } \\
\text { reducing } \\
\text { extract } \\
(\mathrm{g} / \mathrm{L})\end{array}$ & $\begin{array}{l}\text { Acetic acid } \\
\quad(g / L)\end{array}$ & $\begin{array}{l}\text { Amino acid } \\
(\mathrm{mg} / \mathrm{L})\end{array}$ & $\begin{array}{c}\text { Tartaric } \\
\text { acid } \\
(\mathrm{g} / \mathrm{L})\end{array}$ & $\begin{array}{l}\text { L-Malic acid } \\
(\mathrm{g} / \mathrm{L})\end{array}$ & $\begin{array}{c}\text { L-Lactic acid } \\
\text { (g/L) }\end{array}$ \\
\hline & & 2016 & $\begin{array}{c}13.08 \pm 0.68 \\
\text { hiîjklmno }\end{array}$ & $\begin{array}{c}5.51 \pm 0.15 \\
\text { cdefg }\end{array}$ & $\begin{array}{c}0.42 \pm 0.08 \\
\text { defghiîjklmn }\end{array}$ & $\begin{array}{c}8.74 \pm 0.17 \\
\text { defg }\end{array}$ & $\begin{array}{c}26.14 \pm 1.44 \\
\text { abcde }\end{array}$ & $\underset{\text { bcdefg }}{0.26 \pm 0.04}$ & $\underset{\text { klmnopqr }}{15.59 \pm 3.01}$ & $2.96 \pm 0.23^{a}$ & $1.66 \pm 0.59$ cdefghi & ULD \\
\hline & \multirow{3}{*}{ F A. } & 2014 & $\underset{\text { nopqrs }}{12.25 \pm 0.45}$ & $\begin{array}{c}5.33 \pm 0.01 \\
\text { efgh }\end{array}$ & $\begin{array}{l}0.39 \pm 0.05 \\
\text { hiijjklmnop }\end{array}$ & $\underset{\text { mnopqrs }}{5.12 \pm 0.49}$ & $\underset{\text { bcdef }}{25.10 \pm 1.06}$ & $\underset{\text { defghiijk }}{0.21 \pm 0.02}$ & $\underset{\text { Imnopqr }}{15.14 \pm 1.50}$ & $\begin{array}{c}1.67 \pm 0.54 \\
\text { efghiîjkl }\end{array}$ & $1.95 \pm 0.55$ abcdef & ULD \\
\hline & & 2015 & $\begin{array}{c}13.36 \pm 0.34 \\
\text { efghiîjklmno }\end{array}$ & $\begin{array}{c}5.19 \pm 0.19 \\
\text { ghiîj }\end{array}$ & $\begin{array}{c}0.39 \pm 0.05 \\
\text { iîjklmnop }\end{array}$ & $\begin{array}{c}5.52 \pm 0.13 \\
\text { jklmnopq }\end{array}$ & $\underset{\text { fghiîj }}{23.01 \pm 2.09}$ & $\begin{array}{c}0.19 \pm 0.02 \\
\text { efghiijklmno }\end{array}$ & $\begin{array}{c}18.85 \pm 3.03 \\
\text { bcdefghiîjkl }\end{array}$ & $3.27 \pm 0.16^{\mathrm{a}}$ & $1.06 \pm 0.14^{\mathrm{i}}$ & ULD \\
\hline & & 2016 & $\begin{array}{c}12.98 \pm 0.55 \\
\text { hiîjklmnop }\end{array}$ & $\begin{array}{c}5.41 \pm 0.17 \\
\text { defgh }\end{array}$ & $\begin{array}{c}0.43 \pm 0.02 \\
\text { defghiîjklm }\end{array}$ & $\begin{array}{c}9.63 \pm 0.52 \\
\text { bcde }\end{array}$ & $\underset{\text { fghiîj }}{23.36 \pm 2.39}$ & $\begin{array}{c}0.27 \pm 0.06 \\
\text { abcdef }\end{array}$ & $\begin{array}{c}17.46 \pm 0.53 \\
\text { efghiîjklmnop }\end{array}$ & $\begin{array}{c}1.70 \pm 0.55 \\
\text { efghiîjkl }\end{array}$ & $1.33 \pm 0.10^{\text {fghi }}$ & ULD \\
\hline & \multirow{3}{*}{ F R. } & 2014 & $\begin{array}{c}11.88 \pm 0.57 \\
\text { opqrs }\end{array}$ & $\underset{\text { fghi }}{5.25 \pm 0.06}$ & $0.51 \pm 0.06$ & $10.48 \pm 0.66$ & $\underset{\text { hiîjk }}{21.40 \pm 1.40}$ & $\begin{array}{c}0.17 \pm 0.05 \\
\text { hiîklmnop }\end{array}$ & $\begin{array}{c}17.37 \pm 3.47 \\
\text { efghiîjklmnop }\end{array}$ & $2.52 \pm \underset{\text { bcd }}{0.88}$ & $2.51 \pm 0.12^{a b}$ & ULD \\
\hline & & 2015 & $11.29 \pm 1.11^{\mathrm{rs}}$ & $4.37 \pm 0.12^{\mathrm{p}}$ & $\begin{array}{c}0.45 \pm 0.07 \\
\text { cdefgiîjkl }\end{array}$ & $\begin{array}{c}5.74 \pm 1.03 \\
\text { jklmnop }\end{array}$ & $\begin{array}{c}23.34 \pm 1.13 \\
\text { fghiîj }\end{array}$ & $\begin{array}{c}0.17 \pm 0.06 \\
\text { iîjklmnopq }\end{array}$ & $\begin{array}{c}18.85 \pm 3.02 \\
\text { bedefghiijkl }\end{array}$ & $\underset{\text { fghiijkl }}{1.63 \pm 0.61}$ & $1.63 \pm 0.61^{\text {cdefghi }}$ & ULD \\
\hline & & 2016 & $\underset{\text { klmnopq }}{12.52 \pm 0.33}$ & $\begin{array}{l}4.99 \pm 0.11 \\
\text { iijjklm }\end{array}$ & $\begin{array}{c}0.52 \pm 0.07 \\
\text { abcdefg }\end{array}$ & $\begin{array}{c}10.59 \pm 0.55 \\
\mathrm{ab}\end{array}$ & $\begin{array}{c}21.45 \pm 0.95 \\
\text { iijjk }\end{array}$ & $\begin{array}{c}0.19 \pm 0.02 \\
\text { efghiijklmno }\end{array}$ & $\begin{array}{c}19.28 \pm 1.74 \\
\text { abcdefghiîjk }\end{array}$ & $1.22 \pm 0.18^{1}$ & $1.93 \pm 1.12^{\text {abcdefg }}$ & ULD \\
\hline & \multirow{3}{*}{ F N. } & 2014 & $\begin{array}{c}13.26 \pm 0.72 \\
\text { fghiîjklmno }\end{array}$ & $\begin{array}{c}4.70 \pm 0.49 \\
\text { Imnop }\end{array}$ & $\begin{array}{c}0.39 \pm 0.06 \\
\text { ghiijklmnop }\end{array}$ & $\begin{array}{c}4.70 \pm 0.63 \\
\text { opqrsș }\end{array}$ & $\underset{\text { ghiîjk }}{22.73 \pm 1.00}$ & $0.27 \pm 0.05$ & $\underset{\text { abcdefghi }}{20.15 \pm 1.96}$ & $\begin{array}{c}2.19 \pm 0.13 \\
\text { cdefgh }\end{array}$ & $1.23 \pm 0.01^{\mathrm{i}}$ & ULD \\
\hline & & 2015 & $\underset{\text { cdefghîi }}{13.92 \pm 0.53}$ & $\begin{array}{c}5.10 \pm 0.07 \\
\text { hiîjk }\end{array}$ & $\begin{array}{c}0.37 \pm 0.06 \\
\text { jklmnop }\end{array}$ & $\begin{array}{c}8.52 \pm 0.74 \\
\text { efgh }\end{array}$ & $\underset{\mathrm{abc}}{27.08 \pm 0.44}$ & $\begin{array}{c}0.16 \pm 0.04 \\
\text { îjklmnopq }\end{array}$ & $\begin{array}{c}19.55 \pm 1.52 \\
\text { abcdefghiij }\end{array}$ & $\begin{array}{c}2.03 \pm 0.52 \\
\text { cdefghiìjk }\end{array}$ & $1.38 \pm 0.25$ efghi & ULD \\
\hline & & 2016 & $\begin{array}{c}13.18 \pm 0.29 \\
\text { hiijjklmo }\end{array}$ & $\underset{\text { fghi }}{5.24 \pm 0.11}$ & $\begin{array}{c}0.43 \pm 0.03 \\
\text { defghiijklm }\end{array}$ & $\begin{array}{c}5.81 \pm 0.47 \\
\text { jklmno }\end{array}$ & $\underset{\text { ghiijk }}{22.44 \pm 0.99}$ & $\begin{array}{c}0.19 \pm 0.02 \\
\text { efghiijklmno }\end{array}$ & $\underset{\text { nopqrs }}{14.63 \pm 0.70}$ & $\begin{array}{c}1.86 \pm 0.42 \\
\text { defghiijkl }\end{array}$ & $1.26 \pm 0.07 \mathrm{hi}$ & ULD \\
\hline & \multirow{3}{*}{$\mathbf{M}$} & 2014 & $\underset{\text { defghiijjkl }}{13.52 \pm 1.11}$ & $\begin{array}{c}4.55 \pm 0.01 \\
\text { mnop }\end{array}$ & $0.30 \pm 0.06^{\mathrm{p}}$ & $7.33 \pm 0.55$ hî̀ & $\begin{array}{c}20.84 \pm 0.90 \\
j \mathrm{k}\end{array}$ & $\begin{array}{c}0.16 \pm 0.06 \\
\text { ijjklmnopq }\end{array}$ & $\begin{array}{c}15.95 \pm 1.41 \\
\text { jklmnopqrs }\end{array}$ & $\begin{array}{c}1.60 \pm 0.64 \\
\text { ghiijijkl }\end{array}$ & $1.62 \pm 0.01$ defghi & ULD \\
\hline & & 2015 & $\begin{array}{c}12.37 \pm 0.07 \\
\text { Imnopgrs }\end{array}$ & $5.82 \pm 0.40^{\mathrm{bc}}$ & $\begin{array}{c}0.33 \pm 0.05 \\
\text { Imnop }\end{array}$ & $\begin{array}{c}5.29 \pm 0.56 \\
\text { klmnopq }\end{array}$ & $\begin{array}{c}23.77 \pm 3.23 \\
\text { efghiî }\end{array}$ & $\begin{array}{c}0.20 \pm 0.02 \\
\text { defghiîjklmn }\end{array}$ & $\begin{array}{c}14.92 \pm 3.01 \\
\text { mnopqrs }\end{array}$ & $\underset{\text { bcd }}{2.54 \pm 1.15}$ & $1.90 \pm 0.60$ bcdefgh & ULD \\
\hline & & 2016 & $\underset{\text { jklmnopq }}{12.59 \pm 1.28}$ & $\underset{\text { cde }}{5.66 \pm 0.29}$ & $\begin{array}{c}0.32 \pm 0.03 \\
\text { mnop }\end{array}$ & $\underset{\text { ghiî }}{7.41 \pm 1.80}$ & $\underset{\text { ghiijjk }}{22.67 \pm 1.52}$ & $\begin{array}{c}0.19 \pm 0.07 \\
\text { efghiijklmno }\end{array}$ & $\underset{\text { abcdefgh }}{20.48 \pm 1.38}$ & $\begin{array}{c}2.23 \pm 0.19 \\
\text { cdefg }\end{array}$ & $1.99 \pm 0.47$ abcde & ULD \\
\hline & \multirow{3}{*}{ C S. } & 2014 & $\begin{array}{c}12.92 \pm 0.74 \\
\text { iîjklmno }\end{array}$ & $6.04 \pm 0.13^{b}$ & $\begin{array}{c}0.39 \pm 0.05 \\
\text { ghiijklmnop }\end{array}$ & $2.45 \pm 0.20^{t}$ & $\underset{\text { defghi }}{24.19 \pm 2.21}$ & $\begin{array}{c}0.21 \pm 0.03 \\
\text { defghiîjkl }\end{array}$ & $\begin{array}{c}18.74 \pm 0.39 \\
\text { bcdefghiîjklm }\end{array}$ & $1.34 \underset{\mathrm{jkl}}{ \pm 0.01}$ & $1.26 \pm 0.06 \mathrm{hi}$ & ULD \\
\hline & & 2015 & $\underset{\text { nopqrs }}{12.19 \pm 0.26}$ & $\begin{array}{c}5.32 \pm 0.04 \\
\text { efgh }\end{array}$ & $\begin{array}{c}0.43 \pm 0.11 \\
\text { defghiîjklmn }\end{array}$ & $\begin{array}{c}4.67 \pm 0.57 \\
\text { opqrsșt }\end{array}$ & $\begin{array}{c}22.07 \pm 0.44 \\
\text { ghiijk }\end{array}$ & $\begin{array}{c}0.23 \pm 0.06 \\
\text { cdefghiijkk }\end{array}$ & $\underset{\text { abcdefghiî }}{20.22 \pm 0.77}$ & $1.30 \pm 0.07^{\mathrm{kl}}$ & $1.97 \pm 0.64$ abcde & ULD \\
\hline & & 2016 & $\underset{\text { pqrs }}{11.63 \pm 0.59}$ & $\underset{\text { cdef }}{5.59 \pm 0.13}$ & $\begin{array}{c}0.41 \pm 0.03 \\
\text { efghiîjklmno }\end{array}$ & $\begin{array}{c}5.71 \pm 0.55 \\
\text { jklmnop }\end{array}$ & $\begin{array}{c}21.67 \pm 0.59 \\
\text { hiîjk }\end{array}$ & $\begin{array}{c}0.20 \pm 0.02 \\
\text { defghiîjklmn }\end{array}$ & $\begin{array}{c}16.26 \pm 1.67 \\
\text { iìjklmnopqr }\end{array}$ & $3.20 \pm 0.05^{\mathrm{a}}$ & $2.20 \pm 0.11^{\mathrm{abcd}}$ & ULD \\
\hline
\end{tabular}

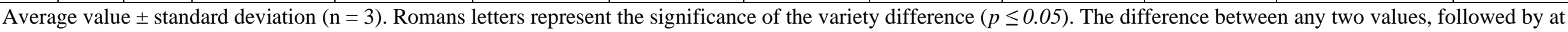

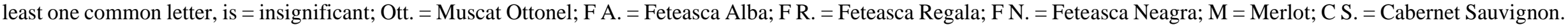
$\mathrm{ULD}=$ under the limit of detection. 
Table 5. The ${ }^{206} \mathrm{~Pb} /{ }^{207} \mathrm{~Pb},{ }^{208} \mathrm{~Pb} / 206 \mathrm{~Pb},{ }^{206} \mathrm{~Pb} / 204 \mathrm{~Pb},{ }^{87} \mathrm{Sr} /{ }^{86} \mathrm{Sr}$, isotope rations obtained from wine samples from Dealu Bujorului Vineyard (Bujoru, Smulți and Oancea Wine Centre)

\begin{tabular}{|c|c|c|c|c|c|c|c|c|c|c|c|c|c|}
\hline U⿺辶ّ & 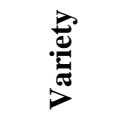 & $\stackrel{\check{\nexists}}{\ddot{\nu}}$ & ${ }^{206} \mathrm{~Pb} /{ }^{207} \mathrm{~Pb}$ & SD & ${ }^{208} \mathrm{~Pb} /{ }^{206} \mathrm{~Pb}$ & SD & $\begin{array}{c}\text { RSD } \\
(\%)\end{array}$ & ${ }^{206} \mathrm{~Pb} /{ }^{204} \mathrm{~Pb}$ & $\begin{array}{c}\text { RSD } \\
(\%)\end{array}$ & ${ }^{87} \mathrm{Sr} /{ }^{86} \mathrm{Sr}$ & $\begin{array}{l}\text { RSD } \\
(\%)\end{array}$ & $\begin{array}{c}\mathrm{Pb}(\mu \mathrm{g} / \mathrm{L}) \\
\text { M.A.L.* } \\
\text { 0.15 mg/L }\end{array}$ & $\begin{array}{c}\mathrm{Sr}(\boldsymbol{\mu g} / \mathrm{L}) \\
\text { M.A.L.*** } \\
-\end{array}$ \\
\hline \multirow{18}{*}{ 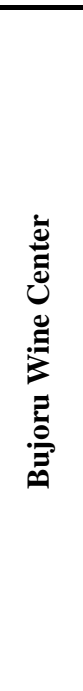 } & \multirow{3}{*}{ M Ott. } & 2014 & $1.13254^{\mathrm{ijk}} \beta \gamma \delta$ & 0.00036 & $2.12629^{\text {cde }} \beta \gamma$ & 0.00053 & 0.09456 & $17.46918^{\mathrm{d}} \alpha$ & 0.09456 & $0.71240^{\mathrm{klm}} \varepsilon$ & 0.01725 & $\begin{array}{c}39.93 \pm 1.93^{\operatorname{lmno}} \\
\alpha \beta \gamma\end{array}$ & $133.64 \pm 3.49^{\mathrm{p}} 1$ \\
\hline & & 2015 & $1.12757^{\mathrm{klm}} \gamma \delta \varepsilon$ & 0.00452 & $2.14190^{\mathrm{a}} \alpha$ & 0.00743 & 0.34696 & $17.43110^{\mathrm{de}} \alpha \beta \gamma$ & 0.12536 & $0.71572^{\mathrm{ijk} \delta} \delta \varepsilon$ & 0.44613 & $41.95 \pm 1.60^{\mathrm{klm}} \alpha$ & $152.57 \pm 4.74^{\mathrm{n}} \theta$ \\
\hline & & 2016 & $1.12391^{\mathrm{m}} \varepsilon$ & 0.00133 & $2.12926^{\mathrm{bcd}} \beta \gamma$ & 0.00799 & 0.37512 & $17.41786^{\mathrm{de}} \beta \gamma$ & 0.03015 & $0.72304^{\mathrm{gh}} \alpha \beta$ & 0.41614 & $26.22 \pm 1.16^{\mathrm{yw}} \zeta$ & $326.81 \pm 2.05^{\mathrm{b}} \alpha$ \\
\hline & \multirow{3}{*}{$\begin{array}{c}\mathbf{F} \\
\mathbf{A} .\end{array}$} & 2014 & $1.14202^{\mathrm{efg}} \alpha$ & 0.00822 & $2.12488^{\text {cde }} \beta \gamma$ & 0.00288 & 0.13531 & $17.43660^{\mathrm{de}} \alpha \beta \gamma$ & 0.07738 & $0.72135^{\text {ghi }} \alpha \beta$ & 0.04199 & $36.29 \pm 1.63^{\mathrm{opr}} \beta \gamma \delta$ & $273.79 \pm 5.29^{\mathrm{d}} \gamma$ \\
\hline & & 2015 & $1.13349^{\mathrm{ijk}} \beta \gamma$ & 0.00188 & $2.12629^{\text {cde }} \beta \gamma$ & 0.00539 & 0.25334 & $17.39880^{\mathrm{e}} \beta \gamma$ & 0.20089 & $0.71227^{\mathrm{klm}} \varepsilon$ & 0.03451 & $41.73 \pm 3.38^{\mathrm{klm}} \alpha$ & $214.67 \pm 2.41^{\text {hi } \zeta}$ \\
\hline & & 2016 & $1.12772^{\mathrm{klm}} \gamma \delta \varepsilon$ & 0.00423 & $2.12378^{\text {cde }_{\gamma}}$ & 0.00190 & 0.08933 & $17.31524^{\mathrm{f}} \delta$ & 0.03479 & $0.71810^{\mathrm{hij}} \gamma \delta$ & 0.83133 & $40.50 \pm 2.08^{\mathrm{lmn}} \alpha \beta$ & $109.39 \pm 1.32^{\mathrm{tu}^{\mathrm{u}}} \kappa$ \\
\hline & \multirow{3}{*}{ F R. } & 2014 & $1.13487^{\mathrm{ijh}} \beta \gamma$ & 0.00233 & $2.12289^{\mathrm{de}} \gamma$ & 0.00058 & 0.02748 & $17.39163^{\mathrm{e}} \gamma$ & 0.41595 & $0.71844^{\mathrm{hij}} \beta \gamma \delta$ & 0.69694 & $26.90 \pm 2.41^{\mathrm{xy} \zeta}$ & $214.94 \pm 0.87^{\text {hi }} \zeta$ \\
\hline & & 2015 & $1.13349^{\mathrm{ijk}} \beta \gamma$ & 0.00188 & $2.12228^{\mathrm{e}} \gamma$ & 0.00081 & 0.03830 & $17.42611^{\mathrm{de}} \alpha \beta \gamma$ & 0.12511 & $0.72156^{\mathrm{gh}} \alpha \beta$ & 0.01270 & $33.20 \pm 2.56^{\text {rst }} \delta \varepsilon$ & $217.20 \pm 1.79^{\mathrm{h} \zeta}$ \\
\hline & & 2016 & $1.12776^{\mathrm{klm}} \gamma \delta \varepsilon$ & 0.00422 & $2.12258^{\mathrm{e}} \gamma$ & 0.00234 & 0.11034 & $17.43908^{\mathrm{de}} \alpha \beta \gamma$ & 0.13200 & $0.72208^{\mathrm{gh}} \alpha \beta$ & 0.15312 & $35.78 \pm 3.33^{\mathrm{prs}} \gamma \delta$ & $181.55 \pm 3.05^{1} \eta$ \\
\hline & \multirow{4}{*}{ F N. } & 2014 & $1.13469^{\text {hiji }} \beta \gamma$ & 0.00219 & $2.12569^{\text {cde }} \beta \gamma$ & 0.00040 & 0.01862 & $17.42780^{\mathrm{de}} \alpha \beta \gamma$ & 0.11945 & $0.72602^{\operatorname{defg}_{\alpha}}$ & 0.57532 & $30.29 \pm 0.78^{\mathrm{utvx}} \varepsilon \zeta$ & $234.15 \pm 5.53^{\mathrm{g}} \mathcal{E}$ \\
\hline & & 2015 & $1.13547^{\text {ghij }} \alpha \beta$ & 0.00083 & $2.12975^{\mathrm{bc}} \beta \gamma$ & 0.00448 & 0.21026 & $17.42310^{\mathrm{de}} \alpha \beta \gamma$ & 0.05384 & $0.72529^{\mathrm{fg}} \alpha$ & 0.05395 & $26.18 \pm 3.10^{\mathrm{yw}} \zeta$ & $325.16 \pm 4.00^{\mathrm{b}} \alpha$ \\
\hline & & 2016 & $1.12776^{\mathrm{klm}} \gamma \delta \varepsilon$ & 0.00339 & $2.12600^{\text {cde }} \beta \gamma$ & 0.00640 & 0.30112 & $17.42147^{\mathrm{de}} \beta \gamma$ & 0.00080 & $0.72568^{\mathrm{efg}} \alpha$ & 0.11648 & $32.79 \pm 2.67^{\mathrm{rst}} \delta \varepsilon$ & $300.14 \pm 1.96^{\mathrm{c}} \beta$ \\
\hline & & 2014 & $1.12938^{\mathrm{jklm}} \beta \gamma \delta \varepsilon$ & 0.00559 & $2.12790^{\text {cde }} \beta \gamma$ & 0.00379 & 0.17816 & $17.40896^{\mathrm{e}} \beta \gamma$ & 0.03385 & $0.72298^{\mathrm{gh}} \alpha \beta$ & 0.34219 & $33.43 \pm 1.03^{\text {rst }} \delta \varepsilon$ & $107.49 \pm 2.08^{\mathrm{u}_{\kappa}}$ \\
\hline & \multirow[t]{3}{*}{$\mathbf{M}$} & 2015 & $1.12305^{\mathrm{m}} \mathcal{\varepsilon}$ & 0.00266 & $2.13343^{\mathrm{b}} \beta$ & 0.00150 & 0.07040 & $17.41815^{\mathrm{de}} \beta \gamma$ & 0.03441 & $0.72523^{\mathrm{fg}} \alpha$ & 0.07722 & $35.89 \pm 2.42^{\mathrm{prs}} \gamma \delta$ & $261.40 \pm 6.37^{\mathrm{e}} \delta$ \\
\hline & & 2016 & $1.12773^{\mathrm{klm}} \gamma \delta \varepsilon$ & 0.00333 & $2.12418^{\mathrm{cde}} \gamma$ & 0.00093 & 0.04382 & $17.39969^{\mathrm{e}} \beta \gamma$ & 0.17041 & $0.71430^{\mathrm{jkl}} \delta \varepsilon$ & 0.21700 & $41.20 \pm 1.81^{\mathrm{klmn}} \alpha$ & $276.10 \pm 2.00^{\mathrm{d}} \gamma$ \\
\hline & & 2014 & $1.13161^{\mathrm{ijkl}} \beta \gamma \delta$ & 0.00560 & $2.13011^{\mathrm{bc}} \beta \gamma$ & 0.00619 & 0.29060 & $17.42141^{\mathrm{de}} \beta \gamma$ & 0.02771 & $0.72339^{\mathrm{gh}} \alpha$ & 0.28125 & $41.78 \pm 2.24{ }^{\mathrm{klm}} \alpha$ & $130.23 \pm 1.62^{\mathrm{pr}_{1}}$ \\
\hline & \multirow[t]{2}{*}{ C S. } & 2015 & $1.12391^{\mathrm{m}} \varepsilon$ & 0.00133 & $2.12701^{\text {cde }} \beta \gamma$ & 0.00652 & 0.30661 & $17.41199^{\operatorname{de}} \beta \gamma$ & 0.06782 & $0.72254^{\mathrm{gh}} \alpha \beta$ & 0.23652 & $42.06 \pm 3.12^{\mathrm{kl}} \alpha$ & $109.72 \pm 0.83^{\text {tu }} \kappa$ \\
\hline & & 2016 & $1.13320^{\mathrm{ijk}} \beta \gamma$ & 0.00203 & $2.12657^{\mathrm{ecd}} \beta \gamma$ & 0.00431 & 0.20260 & $17.44611^{\mathrm{de}} \alpha \beta$ & 0.12788 & $0.72137^{\text {ghi }} \alpha \beta$ & 0.03197 & $40.99 \pm 3.71^{\mathrm{klmn}} \alpha$ & $216.08 \pm 2.56^{\mathrm{h} \zeta}$ \\
\hline \multirow{18}{*}{ 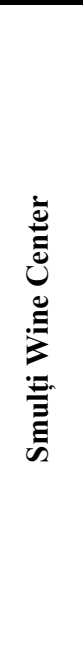 } & \multirow{3}{*}{ M Ott. } & 2014 & $1.18229^{\mathrm{abc}} \alpha \beta \gamma$ & 0.00028 & $2.10364^{\mathrm{fg}} \alpha \beta$ & 0.00108 & 0.05110 & $17.21643^{\mathrm{g}} \gamma \delta$ & 0.02526 & $0.73086^{\text {bcdef }} \beta \gamma$ & 0.15148 & $22.80 \pm 1.75^{\mathrm{wz}} \zeta \eta$ & $116.56 \pm 2.75^{\mathrm{s}} \lambda$ \\
\hline & & 2015 & $1.18415^{\mathrm{ab}} \alpha \beta \gamma$ & 0.00210 & $2.10266^{\mathrm{fgh}} \alpha \beta$ & 0.00041 & 0.01973 & $17.21351^{\mathrm{g}} \gamma \delta$ & 0.01071 & $0.73455^{\mathrm{b}} \beta$ & 0.51894 & $37.79 \pm 1.10^{\text {nop }} \delta$ & $245.14 \pm 4.02^{\mathrm{f}} \beta$ \\
\hline & & 2016 & $1.18523^{\mathrm{a}} \alpha \beta$ & 0.00107 & $2.10723^{\mathrm{fg}} \alpha \beta$ & 0.00501 & 0.23773 & $17.22768^{\mathrm{g}} \alpha$ & 0.03155 & $0.73304^{\mathrm{bc}} \beta \gamma$ & 0.41046 & $32.89 \pm 2.03^{\mathrm{rst}} \varepsilon$ & $258.09 \pm 1.29^{\mathrm{e}} \alpha$ \\
\hline & \multirow{3}{*}{$\begin{array}{l}\mathbf{F} \\
\text { A. }\end{array}$} & 2014 & $1.18502^{\mathrm{a}} \alpha \beta$ & 0.00235 & $2.10382^{\mathrm{fg}} \alpha \beta$ & 0.00206 & 0.09777 & $17.21852^{\mathrm{g}} \beta \gamma \delta$ & 0.03237 & $0.73127^{\text {bcde }} \beta \gamma^{\mathrm{f}}$ & 0.14192 & $28.13 \pm 3.16^{\mathrm{vxy}} \eta$ & $127.65 \pm 1.80^{\mathrm{r}} \kappa$ \\
\hline & & 2015 & $1.17677^{\mathrm{cd}} \gamma \delta$ & 0.00741 & $2.10191^{\mathrm{hijk}} \alpha \beta$ & 0.00040 & 0.01895 & $17.21930^{\mathrm{g}} \beta \gamma$ & 0.03086 & $0.73224^{\mathrm{bc}} \beta \gamma$ & 0.11604 & $30.78 \pm 1.63^{\mathrm{utv}} \varepsilon \zeta \eta$ & $106.62 \pm 1.35^{\mathrm{u}} \xi$ \\
\hline & & 2016 & $1.17765^{\text {bcd }} \beta \gamma \delta$ & 0.00741 & $2.10192^{\mathrm{hijk}} \alpha \beta$ & 0.00054 & 0.02553 & $17.21549^{\mathrm{g}} \gamma \delta$ & 0.03216 & $0.73144^{\text {bcde }} \beta \gamma$ & 0.02684 & $32.30 \pm 0.82^{\text {stu }} \varepsilon \zeta$ & $114.33 \pm 2.15^{\mathrm{st}} \lambda^{\mathrm{s}}$ \\
\hline & \multirow{3}{*}{ F R. } & 2014 & $1.18504^{\mathrm{a}} \alpha \beta$ & 0.00207 & $2.10868^{f} \alpha$ & 0.00592 & 0.28051 & $17.21089^{\mathrm{g}} \delta$ & 0.00677 & $0.73177^{\text {bcde }} \beta \gamma$ & 010621 & $53.16 \pm 1.00^{\mathrm{cd}} \alpha$ & $199.66 \pm 2.60^{\mathrm{j}} \varepsilon$ \\
\hline & & 2015 & $1.18312^{\mathrm{abc}} \alpha \beta \gamma$ & 0.00146 & $2.10741^{\mathrm{fg}} \alpha \beta$ & 0.00457 & 0.21674 & $17.21584^{\mathrm{g}} \gamma \delta$ & 0.02606 & $0.73265^{\mathrm{bc}} \beta \gamma$ & 0.22273 & $51.62 \pm 0.55^{\text {de }} \alpha$ & $176.73 \pm 1.47^{\mathrm{lm}} \eta$ \\
\hline & & 2016 & $1.18452^{\mathrm{a}} \alpha \beta$ & 0.00196 & $2.10153^{\text {hijk }} \beta$ & 0.00053 & 0.02529 & $17.21536^{\mathrm{g}} \gamma \delta$ & 0.03313 & $0.73195^{\mathrm{bcd}} \beta \gamma$ & 0.16894 & $50.29 \pm 0.67^{\operatorname{defg}} \alpha$ & $218.82 \pm 2.67^{\mathrm{h}} \gamma$ \\
\hline & \multirow{4}{*}{ F N. } & 2014 & $1.17462^{\mathrm{d}} \delta$ & 0.00216 & $2.10756^{\mathrm{fg}} \alpha \beta$ & 0.00471 & 0.22341 & $17.21444^{\mathrm{g}} \gamma \delta$ & 0.00703 & $0.73258^{\mathrm{bc}} \beta \gamma$ & 0.91340 & $43.40 \pm 2.65^{\mathrm{jkl}} \beta \gamma$ & $124.29 \pm 7.59^{\mathrm{r}} \kappa$ \\
\hline & & 2015 & $1.18532^{\mathrm{a}} \alpha \beta$ & 0.00109 & $2.10225^{\text {ghij }} \alpha \beta$ & 0.00010 & 0.00467 & $17.21707^{\mathrm{g}} \gamma \delta$ & 0.02226 & $0.73076^{\text {bde }} \beta \gamma^{\mathrm{f}}$ & 0.69139 & $44.73 \pm 3.32^{\mathrm{ijk}} \beta$ & $129.00 \pm 3.76^{\mathrm{pr}} \kappa$ \\
\hline & & 2016 & $1.17784^{\text {bcd }} \beta \gamma \delta$ & 0.00336 & $2.10473^{\mathrm{fg}} \alpha \beta$ & 0.00672 & 0.31908 & $17.21688^{\mathrm{g}} \gamma \delta$ & 0.02298 & $0.74275^{\mathrm{a}} \alpha$ & 0.35191 & $37.59 \pm 1.60^{\text {nop }} \delta$ & $106.86 \pm 2.34^{\mathrm{u}} \xi$ \\
\hline & & 2014 & $1.18597^{\mathrm{a}} \alpha$ & & $2.10190^{\text {hijk }} \alpha \beta$ & 0.0058 & 0.02736 & $17.21491^{\mathrm{g}} \gamma \delta$ & 0.03356 & $0.73152^{\text {bcde }} \beta \gamma$ & 0.00832 & $28.88 \pm 5.32^{\text {tvxy }} \zeta \eta$ & $140.97 \pm 1.56^{\circ} 1$ \\
\hline & \multirow[t]{2}{*}{$\mathbf{M}$} & 2015 & $1.18303^{a b c} \alpha \beta \gamma$ & 0.00268 & $2.10130^{\mathrm{hijk}} \beta$ & 0.00013 & 0.00639 & $17.23090^{\mathrm{g}} \alpha$ & 0.00410 & $0.73077^{\text {bcdef }} \beta \gamma$ & 0.68614 & $22.49 \pm 1.20^{\mathrm{z}} \theta$ & $179.19 \pm 0.88^{\operatorname{lm}} \eta$ \\
\hline & & 2016 & $1.18098^{\mathrm{abcd}} \alpha \beta \gamma \delta$ & 0.00839 & $2.10242^{\text {ifgh }} \alpha \beta$ & 0.00187 & 0.08896 & $17.22479^{g} \alpha \beta$ & 0.02298 & $0.73402^{\mathrm{b}} \beta$ & 0.20095 & $27.29 \pm 1.16^{\mathrm{vxy}} \eta$ & $153.22 \pm 6.73^{\mathrm{n}} \theta$ \\
\hline & \multirow{3}{*}{ C S. } & 2014 & $1.18515^{\mathrm{a}} \alpha \beta$ & 0.00020 & $2.10206^{\text {hijk }} \alpha \beta$ & 0.00055 & 0.02615 & $17.21491^{\mathrm{g}} \gamma \delta$ & 0.03356 & $0.72750^{\text {cdefg }} \gamma$ & 0.57915 & $43.44 \pm 2.33^{\mathrm{jkl}} \beta \gamma$ & $216.46 \pm 1.81^{\mathrm{h}} \gamma$ \\
\hline & & 2015 & $1.18396^{\mathrm{ab}} \alpha \beta \gamma$ & 0.00130 & $2.10483^{\mathrm{fg}} \alpha \beta$ & 0.00623 & 0.29610 & $17.21343^{\mathrm{g}} \gamma \delta$ & 0.01220 & $0.73239^{\mathrm{bc}} \beta \gamma$ & 0.25200 & $40.47 \pm 0.80^{\operatorname{lmn} \gamma \delta}$ & $209.50 \pm 1.54^{\mathrm{i}} \delta$ \\
\hline & & 2016 & $1.17964^{\mathrm{abcd}} \alpha \beta \gamma \delta$ & 0.00654 & $2.10397^{\mathrm{fg}} \alpha \beta$ & 0.00546 & 0.25930 & $17.21474^{\mathrm{g}} \gamma \delta$ & 0.00203 & $0.73120^{\text {bcdef }} \beta \gamma$ & 0.02999 & $39.47 \pm 1.10^{\mathrm{lmnop}} \delta$ & $192.29 \pm 6.86^{\mathrm{k} \zeta}$ \\
\hline
\end{tabular}


Bora /Carpathian Journal of Food Science and Technology 2019,11(3), 121-139

\begin{tabular}{|c|c|c|c|c|c|c|c|c|c|c|c|c|c|}
\hline$\stackrel{\Xi}{:}$ & 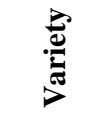 & 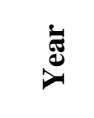 & ${ }^{206} \mathrm{~Pb} /{ }^{207} \mathrm{~Pb}$ & SD & ${ }^{208} \mathrm{~Pb} /{ }^{206} \mathrm{~Pb}$ & SD & $\begin{array}{c}\text { RSD } \\
(\%)\end{array}$ & ${ }^{206} \mathrm{~Pb} /{ }^{204} \mathrm{~Pb}$ & $\begin{array}{c}\text { RSD } \\
(\%)\end{array}$ & ${ }^{87} \mathrm{Sr} /{ }^{86} \mathrm{Sr}$ & $\begin{array}{c}\text { RSD } \\
(\%)\end{array}$ & $\begin{array}{c}\mathrm{Pb}(\mu \mathrm{g} / \mathrm{L}) \\
\text { M.A.L.* } \\
\text { 0.15 mg/L }\end{array}$ & $\begin{array}{c}\mathrm{Sr}(\mu \mathrm{g} / \mathrm{L}) \\
\text { M.A.L.*** } \\
\text { - }\end{array}$ \\
\hline \multirow{3}{*}{\multicolumn{2}{|c|}{ M Ott. }} & 2014 & $1.14230^{\mathrm{ef}} \alpha \beta \gamma$ & 0.00187 & $2.09557^{\mathrm{jkl} \alpha} \alpha$ & 0.00015 & 0.00729 & $17.61229^{\mathrm{c}} \beta \gamma$ & 0.05492 & $0.70165^{\mathrm{p}} \beta \gamma$ & 0.08200 & $55.78 \pm 0.81^{\mathrm{bc}} \beta$ & $174.80 \pm 5.33^{\mathrm{m}} \theta$ \\
\hline & & 2015 & $1.14184^{\mathrm{efg}} \alpha \beta \gamma$ & 0.00286 & $2.09531^{\mathrm{kl}} \alpha$ & 0.00026 & 0.01218 & $17.61543^{\mathrm{c}} \beta \gamma$ & 0.02934 & $0.70788^{\mathrm{mno}} \alpha \beta \gamma$ & 1.35361 & $57.36 \pm 1.38^{\mathrm{b}} \beta$ & $192.81 \pm 3.20^{\mathrm{k}} \eta$ \\
\hline & & 2016 & $1.14537^{\mathrm{e}} \alpha \beta$ & 0.00268 & $2.09557^{\mathrm{jkl}} \alpha$ & 0.00010 & 0.00482 & $17.61396^{c} \beta \gamma$ & 0.08560 & $0.70326^{\mathrm{op}} \beta \gamma$ & 0.10740 & $48.46 \pm 0.85^{\mathrm{efg}} \delta \varepsilon$ & $187.54 \pm 2.93^{\mathrm{k}} \eta$ \\
\hline \multirow{4}{*}{\multicolumn{2}{|c|}{$\begin{array}{c}\mathbf{F} \\
\mathbf{A} .\end{array}$}} & 2014 & $1.14212^{\mathrm{efg}} \alpha \beta \gamma$ & 0.00166 & $2.09541^{\mathrm{kl}} \alpha$ & 0.00001 & 0.00028 & $17.70222^{\mathrm{ab}} \alpha \beta$ & 0.15455 & $0.70221^{\mathrm{op}} \beta \gamma$ & 0.01809 & $57.28 \pm 0.81^{\mathrm{b}} \beta$ & $193.09 \pm 3.07^{\mathrm{k}} \eta$ \\
\hline & & 2015 & $1.14018^{\mathrm{efgh}} \gamma$ & 0.00003 & $2.09404^{1} \alpha \beta$ & 0.00230 & 0.10978 & $17.64307^{\mathrm{c}} \alpha \beta \gamma$ & 0.24352 & $0.70247^{\circ \mathrm{op}} \beta \gamma$ & 0.08219 & $27.32 \pm 1.52^{\mathrm{vxy}} \eta$ & $273.46 \pm 4.00^{\mathrm{d}} \gamma$ \\
\hline & & 2016 & $1.14605^{\mathrm{e}} \alpha$ & 0.00169 & $2.09651^{\mathrm{ijkl} \alpha} \alpha$ & 0.00168 & 0.02529 & $17.64396^{\mathrm{c}} \beta \gamma$ & 0.08560 & $0.70175^{\mathrm{op}} \beta \gamma$ & 0.04854 & $42.63 \pm 1.05^{\mathrm{kl}} \zeta$ & $216.14 \pm 2.66^{\mathrm{h}} \zeta$ \\
\hline & & 2014 & $1.14121^{\mathrm{efgh}} \beta \gamma$ & 0.00173 & $2.09412^{1} \alpha \beta$ & 0.00171 & 0.22341 & $17.61823^{\mathrm{c}} \beta \gamma$ & 0.06862 & $0.70171^{\mathrm{P}} \beta \gamma$ & 0.11789 & $47.57 \pm 2.25^{\mathrm{fgh}} \varepsilon$ & $260.66 \pm 3.04^{\mathrm{e}} \delta$ \\
\hline \multirow{3}{*}{\multicolumn{2}{|c|}{ F R. }} & 2015 & $1.14435^{\mathrm{e}} \alpha \beta \gamma$ & 0.00390 & $2.09528^{\mathrm{kl}} \alpha$ & 0.00028 & 0.01323 & $17.61146^{\mathrm{c}} \beta \gamma$ & 0.06004 & $0.70288^{\circ p} \beta \gamma$ & 0.20128 & $51.54 \pm 2.90^{\mathrm{de}} \gamma$ & $244.49 \pm 3.51^{\mathrm{f}} \varepsilon$ \\
\hline & & 2016 & $1.14629^{\mathrm{e}} \alpha$ & 000142 & $2.09411^{1} \alpha \beta$ & 0.00105 & 0.04990 & $17.6127^{\mathrm{c}} \beta \gamma$ & 0.05553 & $0.70542^{\text {nop }} \beta \gamma$ & 0.97519 & $51.20 \pm 1.44^{\mathrm{def}} \gamma$ & $215.68 \pm 0.78^{\mathrm{h}} \zeta$ \\
\hline & & 2014 & $1.14114^{\mathrm{efgh}} \beta \gamma$ & 0.00163 & $2.09576^{\mathrm{jkl}} \alpha$ & 0.00076 & 0.03433 & $17.62720^{c} \alpha \beta \gamma$ & 0.11928 & $0.70560^{\text {nop }} \beta \gamma$ & 0.68843 & $50.18 \pm 2.18^{\operatorname{defg}} \gamma \delta$ & $326.16 \pm 2.66^{\mathrm{b}} \beta$ \\
\hline \multirow{3}{*}{\multicolumn{2}{|c|}{ F N. }} & 2015 & $1.14435^{\mathrm{e}} \alpha \beta \gamma$ & 0.00390 & $2.09528^{\mathrm{kl}} \alpha$ & 0.00028 & 0.01323 & $17.63062^{c} \alpha \beta \gamma$ & 0.11989 & $0.71448^{\mathrm{jkl}} \alpha$ & 0.25095 & $51.66 \pm 1.87^{\text {de }} \gamma$ & $249.15 \pm 4.62^{\mathrm{f}} \varepsilon$ \\
\hline & & 2016 & $1.14500^{\mathrm{e}} \alpha \beta$ & 0.00317 & $2.09577^{\mathrm{jkl} \alpha}$ & 0.00074 & 0.03537 & $17.60973^{\mathrm{c}} \gamma$ & 0.04787 & $0.70916^{\operatorname{lmn}} \alpha \beta$ & 1.03156 & $61.33 \pm 1.21^{\mathrm{a}} \alpha$ & $270.16 \pm 1.00^{\mathrm{d}} \gamma$ \\
\hline & & 2014 & $1.14121^{\mathrm{efgh}} \beta \gamma$ & 0.00177 & $2.09612^{\mathrm{ijkl} \alpha} \alpha$ & 0.00149 & 0.07126 & $17.70857^{a} \beta \gamma$ & 0.94776 & $0.70112^{\mathrm{p}} \gamma$ & 0.10738 & $36.59 \pm 1.13^{\mathrm{opr}} \eta$ & $249.43 \pm 2.40^{\mathrm{f}} \varepsilon$ \\
\hline \multirow{3}{*}{\multicolumn{2}{|c|}{$\mathbf{M}$}} & 2015 & $1.14287^{\mathrm{ef}} \alpha \beta \gamma$ & 0.00435 & $2.09556^{\mathrm{jkl}} \alpha$ & 0.00010 & 0.00468 & $17.63746^{\mathrm{c}} \alpha \beta \gamma$ & 0.06768 & $0.70412^{\text {nop }} \beta \gamma$ & 0.35258 & $40.93 \pm 1.81^{\mathrm{klmn} \zeta}$ & $362.15 \pm 2.90^{\mathrm{a}} \alpha$ \\
\hline & & 2016 & $1.14550^{\mathrm{e}} \alpha \beta$ & 0.00034 & $2.09532^{\mathrm{kl}} \alpha$ & 0.00028 & 0.01338 & $17.61914^{\mathrm{c}} \beta \gamma$ & 0.02278 & $0.70317^{\mathrm{op}} \beta \gamma$ & 0.29783 & $42.13 \pm 0.55^{\mathrm{kl}} \zeta$ & $118.42 \pm 1.12^{\mathrm{s}} \lambda$ \\
\hline & & 2014 & $1.14184^{\mathrm{efg}} \alpha \beta \gamma$ & 0.00286 & $2.09205^{1} \beta$ & 0.00576 & 0.27513 & $17.70857^{\mathrm{a}} \alpha$ & 0.02238 & $0.70203^{\circ \mathrm{p}} \beta \gamma$ & 0.13326 & $55.60 \pm 0.89^{\mathrm{bc}} \beta$ & $148.54 \pm 3.16^{\mathrm{n}} 1 \kappa$ \\
\hline \multirow{2}{*}{\multicolumn{2}{|c|}{ C S. }} & 2015 & $1.14200^{\mathrm{efg}} \alpha \beta \gamma$ & 0.00313 & $2.09565^{\mathrm{jkl}} \alpha$ & 0.00003 & 0.00146 & $17.63840^{\mathrm{c}} \alpha \beta \gamma$ & 0.25064 & $0.70573^{\text {nop }} \beta \gamma$ & 0.69427 & $38.10 \pm 0.79^{\text {mnop }} \eta$ & $114.09 \pm 4.41^{\mathrm{st} \lambda}$ \\
\hline & & 2016 & $1.14407^{\mathrm{e}} \alpha \beta \gamma$ & 0.00224 & $2.09592^{\mathrm{ijkl}} \alpha$ & 0.00052 & 0.02479 & $17.65393^{\mathrm{bc}} \alpha \beta \gamma$ & 0.30105 & $0.70120^{\mathrm{p}} \gamma$ & 0.03128 & $46.66 \pm 0.78^{\mathrm{ghi}} \varepsilon$ & $212.78 \pm 3.86^{\mathrm{hi}} \zeta$ \\
\hline \multicolumn{3}{|c|}{ Average } & 1.15202 & 0.00279 & 2.10878 & 0.00238 & 0.11248 & 17.42240 & 0.09244 & 0.71909 & 0.31542 & $40.64 \pm 1.85$ & $187.36 \pm 3.15$ \\
\hline \multirow{2}{*}{\multicolumn{3}{|c|}{ Minimum Values }} & 1.12305 & 0.00003 & 2.09404 & 0.00001 & 0.00467 & 17.21089 & 0.00080 & 0.70112 & 0.00832 & $22.49 \pm 1.20$ & $107.49 \pm 2.08$ \\
\hline & & & 1.18597 & 0.00839 & 2.14190 & 0.00799 & 0.37512 & 17.70857 & 0.94776 & 0.74275 & 1.35361 & $61.33 \pm 1.21$ & $326.81 \pm 2.05$ \\
\hline \multicolumn{3}{|c|}{ Almeida et al., 2016} & 1.14400 & & 2.15700 & & 1.00000 & & & & & $76.00 \pm 13.00$ & \\
\hline \multicolumn{3}{|c|}{ Avram et al., 2014} & 1.14000 & 0.10000 & 2.10000 & 0.15000 & 7.10000 & & & 0.76000 & 1.30000 & 35.90 & 171.40 \\
\hline \multicolumn{3}{|c|}{ Mihaljevnié et al., 2006} & 1.74000 & 0.00300 & 2.09200 & 0.00700 & & & & & & $11.11 \pm 5.28$ & \\
\hline \multicolumn{3}{|c|}{ Barbaste et al., 2002} & 1.14200 & 0.00200 & 2.12500 & 0.00300 & 0.16000 & 17.60000 & 1.70000 & & & $42.90 \pm 0.05$ & \\
\hline \multicolumn{3}{|c|}{ Geana et al., 2017} & & & & & & & & & & & 905.00 \\
\hline
\end{tabular}

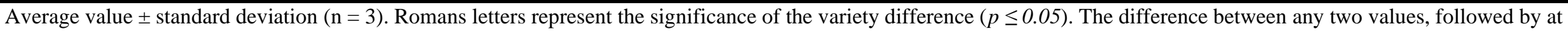

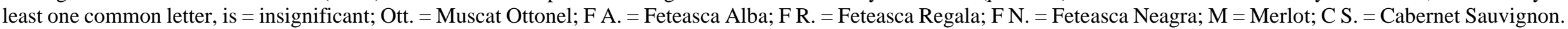

**M.A.L. for $\mathrm{Sr}=$-. 
The cluster heat map is a rectangular tiling of a data matrix cluster trees appended to its margins. Within a relatively compact display area, it facilitates inspection of row, column, and joint cluster structure. Moderately large data matrices (several thousand rows/columns) can be displayed effectively on a high-resolution color monitor and even larger matrices can be handled in print or in megapixel displays.
Heat map was used to discover sample groups, discover groups and also to discover related sample/feature groups. In of elemental contents and ${ }^{206} \mathrm{~Pb} /{ }^{207} \mathrm{~Pb}, \quad{ }^{208} \mathrm{~Pb} /{ }^{206} \mathrm{~Pb}$, ${ }^{206} \mathrm{~Pb} /{ }^{204} \mathrm{~Pb},{ }^{87} \mathrm{Sr} /{ }^{86} \mathrm{Sr}$ isotope ratios from wine (horizontal dendrogram) the dendrogram clearly show two cluster, first cluster is formed from the $\mathrm{Sr}$ and second cluster was formatted from $\mathrm{Pb}$, ${ }^{206} \mathrm{~Pb} /{ }^{204} \mathrm{~Pb}, \quad{ }^{208} \mathrm{~Pb} /{ }^{206} \mathrm{~Pb}, \quad{ }^{206} \mathrm{~Pb} /{ }^{207} \mathrm{~Pb}, \quad$ and ${ }^{87} \mathrm{Sr} /{ }^{86} \mathrm{Sr}$.

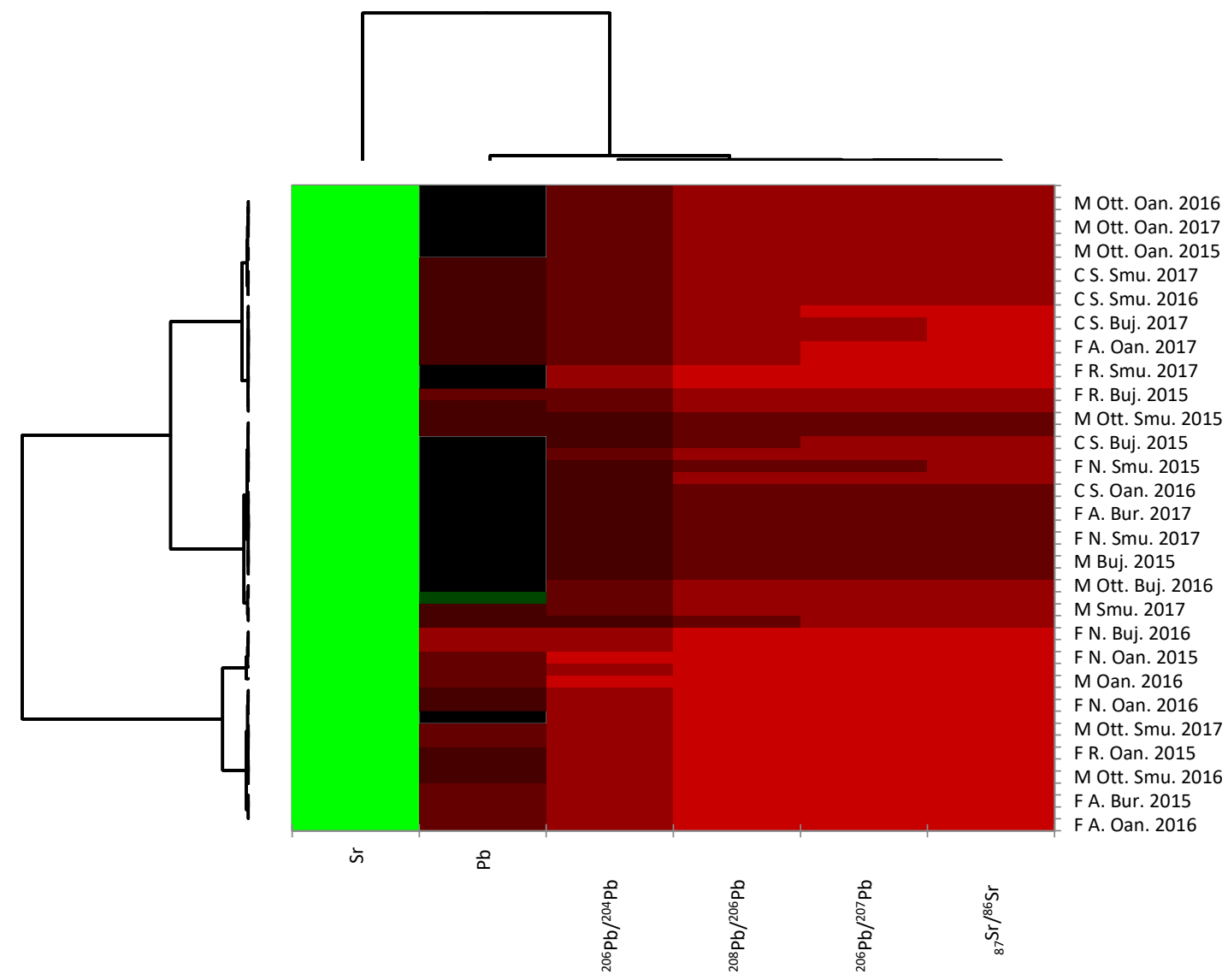

Figure 3. Heat map obtained by cluster analysis of the element contents and ${ }^{206} \mathrm{~Pb} /{ }^{207} \mathrm{~Pb},{ }^{208} \mathrm{~Pb} /{ }^{206} \mathrm{~Pb}$, ${ }^{206} \mathrm{~Pb} /{ }^{204} \mathrm{~Pb},{ }^{87} \mathrm{Sr} /{ }^{86} \mathrm{Sr}$ isotope ratios

Based on this distribution in can be seen that the $\mathrm{Sr}$ recorded the highest values

followed by $\mathrm{Pb}$. The vertical dendrogram show also two cluster, the first M Smu. 2015, C S. Buj. 2015, F R. Buj. 2015, M Buj. 2017, M Oan.
2016, M Oan. 2015, F R. Smu. 2015, F R. Buj. 2017, C S. Smu. 2017, F A. Bur. 2017, F A. Bur. 2015, C S. Buj. 2017, C S. Smu. 2016, F N. Oan. 2016, F N. Oan. 2015 and second cluster was formed from F A. Smu. 2017, M Ott. Smu. 2017, M Ott. Smu. 2016, F R. Oan. 2015, M Ott. Oan. 2017, F R. Oan. 2016, M Buj. 2015, F A. Oan. 
2016, F R. Smu. 2017, C S. Oan. 2016, F A. Smu. 2016, M Ott. Buj. 2017. Based on this distribution in can be seen that there is a separation of wine varieties for white of these red depending on elemental contents and ${ }^{206} \mathrm{~Pb} /{ }^{207} \mathrm{~Pb},{ }^{208} \mathrm{~Pb} /{ }^{206} \mathrm{~Pb},{ }^{206} \mathrm{~Pb} /{ }^{204} \mathrm{~Pb},{ }^{87} \mathrm{Sr} /{ }^{86} \mathrm{Sr}$ isotope ratios, except for a few varieties that do not fit into this rule (F R. Buj. 2015, F R. Smu. 2016, F R. Buj. 2017, F A. Buj. 2017, F A. Buj. 2015 (which have been introduced in red wine cluster)) and M Buj. 2015, C S. Oan. 2016, 2015 (which have been introduced in white wine cluster)) (Figure 3).

\section{Conclusions}

In this work the $\mathrm{Sr}$ and $\mathrm{Pb}$ composition and ${ }^{207} \mathrm{~Pb} /{ }^{206} \mathrm{~Pb},{ }^{208} \mathrm{~Pb} /{ }^{206} \mathrm{~Pb},{ }^{204} \mathrm{~Pb} /{ }^{206} \mathrm{~Pb},{ }^{87} \mathrm{Sr} /{ }^{86} \mathrm{Sr}$ isotope ratio of white wines (Muscat Ottonel, Feteasca Alba, Feteasca Regala) and red wines (Feteasca Neagra, Merlot, Cabernet Sauvignon) production years 2014-2016 from Bujoru, Smulți and Oancea wine-growing centers was studied in order to highlight geographical traceability of elemental composition and isotope ratio for fingerprints of the wines.

Concentration of $\mathrm{Pb}$ in analysed wine samples were under Maximum Limit Allowed (M.L.A.), respectively as published by the Organization of Vine and Wine. The content of potentially toxic elements such as $\mathrm{Pb}$ are lower than the recommended values found in literature, highlighting the safety and quality of the analysed Romanian wines.

From discrimination analysis of wine samples, was found additional new elements Mn and $\mathrm{Cr}$ to tracers for geographical traceability of Romanian wines. Our results confirm that the ${ }^{207} \mathrm{~Pb} /{ }^{206} \mathrm{~Pb}, \quad{ }^{208} \mathrm{~Pb} /{ }^{206} \mathrm{~Pb}, \quad{ }^{204} \mathrm{~Pb} /{ }^{206} \mathrm{~Pb}$ and ${ }^{87} \mathrm{Sr} /{ }^{86} \mathrm{Sr}$ isotope ratio can be used to track the origin of wine, discriminate between the wine produced in different years, and be used to characterize wine terroirs for forensic purpose. The wines obtained in the three wine-growing centers can be geographical fingerprints based on the concentration of $\mathrm{Sr}, \mathrm{Pb}$ and also based on the ${ }^{207} \mathrm{~Pb} /{ }^{206} \mathrm{~Pb}, \quad{ }^{208} \mathrm{~Pb} /{ }^{206} \mathrm{~Pb}, \quad{ }^{204} \mathrm{~Pb} /{ }^{206} \mathrm{~Pb}$, ${ }^{87} \mathrm{Sr} /{ }^{86} \mathrm{Sr}$ isotope ratio. The proposed methodology allowed $100 \%$ successful classification of wines according to the region of provenance and also the years of wine obtaining.

Heat map was discovering a separation of wine varieties for white of this red depending on elemental contents and ${ }^{206} \mathrm{~Pb} /{ }^{207} \mathrm{~Pb},{ }^{208} \mathrm{~Pb} /{ }^{206} \mathrm{~Pb}$, ${ }^{206} \mathrm{~Pb} /{ }^{204} \mathrm{~Pb},{ }^{87} \mathrm{Sr} /{ }^{86} \mathrm{Sr}$ isotope ratios.

\section{References}

Almeida, C. M., Vasconcelos, M. T. (2003). Multielement composition of wines and their precursors including provenance soil and their potentialities as fingerprints of wine origin. Journal of Agricultural and Food Chemistry, 51(16), 4788-4198.

Almeida C. M. S., Almeida A. C., Godoy M. L. D. P., Saint Pierre T. D., Godoy J. M. (2016). Differentiation among Brazilian wie regions based on lead isotopic data. Journal of the Brazilian Chemical Society, 27(6), 10261031.

Aoyama, K., Nakano, T., Shin, K. C., Izawa, A., Morita, S. (2017). Variation of strontium stable isotope rations and origins of strontium in Japanese vegetable and comparison with Chinese vegetables. Food Chemistry, 237, 1186-1195.

Ault, W. U., Senechal, R. G., Erlebach W. E. (1970). Isotopic composition as a natural tracer of lead in our environment. Environmental Science and Technology, 4, 305-313.

Avram, V., Voica C., Hosu A., Cimpoiu C., Măruţoiu C. (2014). ICP-MS characterization of some Roumanian white wines by their mineral content. Revue Roumaine de Chimie, 59 (11), 1009-1019.

Baroni, M. V., Podio, N. S., Badini, R. G., Inga, M., Ostera, H. A., Cognoni, M., Gallegos, E., Gautier, E., Peral-García, P., Hoogewerff, J., Hoogewerff, D. A. (2011). How much do soil and water contribute to the composition of meat? A case study: Meat from three areas of Argentina. Journal of Agricultural and Food Chemistry, 59, 11117-11128.

Barbaste, M., Robinson, K., Guilfoyle, S., Medina, B., Lobinski, R. (2002). Precise determination of the strontium isotope 
rations in wine by inductively coupled plasma sector field multicollector mass spectrometry. Journal of Analytical Atomic Spectrometry, 17, 135-137.

Berglund, M., Wieser M. E. (2011). Isotopic composition of the elements 2009 (IUPAC Technical Report). Pure ad Applied Chemistry, 83(2), 293-306.

Bora, F. D., Pop, T. I., Mihaly, L., Bunea, C. I., Pop, N. (2013). Research on the chemical composition of soil with pollutant effect in some vineyard from North-West Transylvania. Bulletin of University of Agricultural Sciences and Veterinary Medicine Cluj-Napoca, 70 (1), 53-59.

Bora, F. D., Pop, T. I., Babeș, A., Iliescu, M., Popescu, D., Bunea, C, I., Donici, A., Pop, N. (2015). Analysis of micro and macroelements in must and wine of three Vitis vinifera L. varieties, using FAAStechnique. Advances in Agriculture and Botanics-International Journal of the Bioflux Society, 7(3), 217-226.

Bora, F. D., Donici, A., Voica, C., Rusu, T., Mihaly-Cozmuța, L., Mihaly-Cozmuța, A., Cimpoiu, C., Mihăiescu, D. E. (2016). The determination of ${ }^{207} \mathrm{~Pb} /{ }^{206} \mathrm{~Pb},{ }^{208} \mathrm{~Pb} /{ }^{206} \mathrm{~Pb}$, ${ }^{204} \mathrm{~Pb} /{ }^{206} \mathrm{~Pb},{ }^{87} \mathrm{Sr} /{ }^{86} \mathrm{Sr}$ isotope ratio by ICPMS for fingerprinting the South-East Romanian wines. Advances in Agriculture and Botanics - International Journal of the Bioflux Society, 8(3), 129-142.

Bora, F. D., Donici, A., Rusu, T., Bunea, A., Popescu, D., Bunea C. I. (2018). Elemental profile and ${ }^{207} \mathrm{~Pb} /{ }^{206} \mathrm{~Pb},{ }^{208} \mathrm{~Pb} /{ }^{206} \mathrm{~Pb}$, ${ }^{204} \mathrm{~Pb} /{ }^{206} \mathrm{~Pb},{ }^{87} \mathrm{Sr} /{ }^{86} \mathrm{Sr}$ isotope ratio as fingerprints for geographical traceability of Romanian wines. Notulae Botanicae Horti Agrobotanici Cluj-Napoca, 46(1), 223-239.

Cheng, H., Hu, Y. (2010). Lead (Pb) isotopic fingerprinting and its applications in lead pollution studies in China: a review. Environmental Pollution, 158(5), 11341146.

Coetzee, P. P., Steffens, F.E., Eiselen, R. J., Augustyn, O P., Balcaen, L., Vanhaeeke, F. (2005). Multi-element analysis of SouthAfrican wines by ICP-MS and their classification according to geographical origin. Journal of Agricultural and Food Chemistry, 53, 5060-5066.

Durante, C., Baschieri, C., Bertacchini, L., Bertelli, D., Cocchi, M., Marchetti, A., Manzini, D., Papotti, G., Sighiolfi, S. (2015). An analytical approach to $\mathrm{Sr}$ isotope ratio determination in Lambrusco wine for geographical traceability purposes. Food Chemistry, 173, 557-563.

Donici, A., F. D., Bunea, C. I., Călugăr, A. M., Hârşan, E., Bora, F. D. (2019). Investigation of the copper content in vineyard soil, grape, must and wine in the main vineyards of Romania: a preliminary study. Bulletin of University of Agricultural Sciences and Veterinary Medicine Cluj-Napoca, 76(1), 31-46.

Elbaz-Poulichet, F., Holliger P., Huang W. W., Martin J. M. (1984). Lead cycling in estuaries, illustrated by the Gironde estuary, France. Nature, 308, 409-414.

Fortunato, G., Mumic, K., Wunderli, S., Pillonel, L., Bosset, J., Gremaud, G. (2004). Application of strontium isotope abundance ratios measured by MC-ICP-MS for food authentication. Journal of Analytical Atomic Spectrometry, 19, 227-234.

Galani-Nikolakaki, S., Kallithrakas-Kontos, N., Katsanos, A. A. (2002). Trace element analysis of Cretan wines and wine products. Science of the Total Environment, 285(1-3), 155-163.

Geana, E. I., Sandru, C., Stanciu, V., Ionete I. R. (2017). Elemental profile and ${ }^{87} \mathrm{Sr} /{ }^{86} \mathrm{Sr}$ isotope ratio as fingerprints for geographical traceability of wines: an approach on Romanian wines. Food Analytical Methods, 10(1), 63-73.

Gulson, B. L., Tiller, K. G., Mizon, J. K., Merry, E. H. (1981). Use of lead isotopes in soils to identify the source of lead concentration near Adelaide, South Australia. Environmental Science and Technology, 15(6), 691-696.

Gulson, B. L., Lee, T.H., Mizon, K. J., Korsch, M. J., Eschnauer, H. R. (1992). The application of lead isotope ratios to 
determine the contribution on the tin-lead to the content of wine. American Journal of Enology and Viticulture, 43, 180-190.

Hoogewerff, J., Papesch, W., Kralik, M., Berner, M., Vroon, P., Miesbauer, H., Gaber, O., Kunzel, K. H., Kleinjans, J. (2001). The last domicile of the Iceman from Hauslabjoch: a geochemical approach using $\mathrm{Sr}, \mathrm{C}$ and $\mathrm{O}$ isotopes ad trace element signatures. Journal of Archaeological Science, 28, 983-989.

Horn, P., Schaaf, P., Holbach, B., Holzl, S., Eschnauer, H. (1993). ${ }^{87} \mathrm{Sr} /{ }^{86} \mathrm{Sr}$ from rock and soil into vine and wine. Zeitschrift für Lebensmittel-Untersuchung und Forschung, 196, 407-409.

Kelly, S., Heaton, J., Hoogerweff, J. (2005). Tracing the geographical origin of food: the application of multi-element and multiisotope analysis. Trends in Food Science and Technology, 16, 555-567.

Larcher, R., Nicolini, G., Pangrazzi, P. (2003). Isotope rations of lead in Italian wines by inductively coupled plasma mass spectrometry. Journal of Agricultural and Food Chemistry, 51(20), 5956-5961.

Marchionni, S., Buccianti, A., Bollati, A., Braschi, E., Cifelli, F., Molin, P., Parrotto, M., Mattei, M., Tommasini, S., Conticelli, S. (2016). Conservation of (87) $\mathrm{Sr} /(86) \mathrm{Sr}$ isotopic rations during the winemaking processes of "Red" wines to validate their use as geographic tracer. Food Chemistry, 1 (170), 777-785.

Médina, B, Augagneur, S., Barbaste, M., Grouset F. E., Buat-Ménard, P. (2000). Influence of atmospheric pollution on the lead content of wines. Food Additives and Contaminants, 17(6), 435-445.

Mihaljevnié, M., Ettler, V., Šebek, O., Ladislav, C., Vladislav, S. (2006). Lead isotopic signatures of wine and vineyard soils Tracers of lead origin. Journal of Geochemical Exploration, 88(1), 130-133.

Moreno, I. M., Gonzalez-Weller, D, Gutierrez, V., Marino, M., Camean, A. M., Gonzalez, A. G., Hardinsson, A. (2008). Determination of $\mathrm{Al}, \mathrm{Ba}, \mathrm{Ca}, \mathrm{Cu}, \mathrm{Fe}, \mathrm{K}, \mathrm{Mg}, \mathrm{Mn}, \mathrm{Na}, \mathrm{Sr}$ and
$\mathrm{Zn}$ in red wine sample by inductively coupled plasma optical emission spectroscopy: evaluation of preliminary sample treatments. Microchemical Journal, 88, 56-61.

Petrini, R., Sansone, L., Slejko, F. F., Buccianti, A., Marcuzzo, P., Tomasi, D. (2015). The (87) $\mathrm{Sr} /(86) \mathrm{Sr}$ strontium isotopic systematics applied to Glera vineyards: a tracer for the geographical origin of the Prosecco. Food Chemistry, 1(170), 138-144.

Price, T. D., Burton J. H., Bentley, R. A. (2002). The characterization of biologically available strontium isotope ratios for the study of prehistoric migration. Archaeometry, 44, 117-135.

Rosman, K. J. R., Taylor, P. D. P. (1998). Isotopic compositions of elements 1997. Pure ad Applied Chemistry, 70(1), 217-235.

O.I.V. (2015). International Code of Oenological Practices, Annex: Maximum Acceptable Limits, 2015, Issue 2015/01. Paris, France.

Sighinolfi, S., Durante, C., Lisa, L., Tassi, L., Marchetti, A. (2018). Influence of chemical and physical variable on ${ }^{87} \mathrm{Sr} /{ }^{86} \mathrm{Sr}$ isotope ratios determination for geographical traceability studies in the oenological food chain. Beverages, 4(3), 55-68.

Shirahata, H., Elias, R. W., Patterson, C. C., Koide, M. (1980). Chronological variations in concentration and isotopic compositions of anthropogenic atmospheric lead in sediments of a remote subalpine pond. Geochimica et Cosmochimica Acta, 44, 149162.

Stewart, B. W., Copo, R. C., Chadwick, O. A. (1998). Strontium isotopes as tracers of ecosystem processes: theory and methods. Geoderma, 82(1-3), 197-225.

Tommasini, S., Davies, G. R., Elliot, T. (2009). Lead isotope composition of tree rings as bio-geochemical tracers of heavy metals pollution: A reconnaissance study from Firenze, Italy. Applied Geochemistry, 15(7), 891:900.

Trincherini, P. R., Baffi, C., Barbero, P., Pizzoglio, E., Spall, S. (2014). Precise 
determination of strontium isotope ratios by TIMS to authenticate tomato geographical origin. Food Chemistry, 145, 349-355.

Tauler, R., Smilde, A., Kowaski, B. (1995). Selectivity, local rank, 3-way data analysis and ambiguity in multivariate curve resolution. Journal of Chemometrics, 9(1), 31-58.

van der Linde, G., Fischer, J. L., Coetzee, P. P. (2010). Multi-element analysis of South African wines and their provenance soils by ICP-MS and their classification according to geographical origin using multivariate statistics.

Vončina, D. B. (2009). Chemometrics in analytical chemistry. Nova Biotechnologica, 9(2), 211-216.

Voerkelius, S., Lorenz, G. D., Rummel, S., Quétel, C. R., Heiss, G., Baster, M., BrachPapa, C., Deters-Itzelsberger, P., Hoelzl, S., Hoogewerff, J. Ponzevera, E., Van Bocxstaele, M., Ueckerman, H. (2010). Strontium isotopic signatures of natural mineral waters, the reference to a simple geological map and its potential for authentication of food. Food Chemistry, 118, 933-940.

Vorster, C., Greeff, L., Coetzee, P. P. (2010). The determination of ${ }^{11} \mathrm{~B} /{ }^{10} \mathrm{~B}$ and ${ }^{87} \mathrm{Sr} /{ }^{86} \mathrm{Sr}$ isotope rations by quadrupole-based ICPMS for the fingerprinting of South African wine. South Africa Journal of Chemistry, 63, 207-214.

Walker, R. J., Carlson, R. W., Shirey, S. B., Boyd, F. R. (1989). Os, Sr, Nd, and Pb isotope systematics of southern African peridotite xenoliths: Implications for the chemical evaluation of the subcontinental mantle. Geochimica et Cosmochimica Acta, 53, 1583-1595. 